\title{
Molecular characterization and expression profiling of transformer 2 and fruitless-like homologs in the black tiger shrimp, Penaeus monodon
}

\author{
Prawporn Thaijongrak ${ }^{1,2,3}$, Charoonroj Chotwiwatthanakun ${ }^{1,4}$, Phaivit Laphyai ${ }^{1,2}$, Anuphap Prachumwat ${ }^{1,5}$, \\ Thanapong Kruangkum ${ }^{1,2}$, Prasert Sobhon ${ }^{2}$, Rapeepun Vanichviriyakit ${ }^{\text {Corresp. } 1,2}$ \\ ${ }^{1}$ Center of Excellence for Shrimp Molecular Biology and Biotechnology, Faculty of Science, Mahidol University, Bangkok, Bangkok, Thailand \\ 2 Department of Anatomy, Faculty of Science, Mahidol University, Bangkok, Bangkok, Thailand \\ 3 Faculty of Veterinary Science, Mahidol University, Bangkok, Bangkok, Thailand \\ 4 Nakhonsawan Campus, Mahidol University, Nakhonsawan, Thailand \\ 5 National Center for Genetic Engineering and Biotechnology, National Science and Technology Development Agency, Bangkok, Bangkok, Thailand \\ Corresponding Author: Rapeepun Vanichviriyakit \\ Email address: rapeepun.van@mahidol.edu
}

Transformer 2 (tra 2) and fruitless (fru) genes have been proven to play a key role in sex determination pathways in many Arthropods, including insects and crustaceans. In this study, a paralog of $P$. monodon tra 2 (Pmtra 2), P. monodon ovarian associated transformer 2 (PmOvtra 2) and 2 isoforms of $P$. monodon fruitless-like gene (Pmfru-1 and Pmfru-2) were identified and characterized. The full cDNA sequence of PmOvtra 2 consisted of 1,774 bp with the longest open reading frame (ORF) of $744 \mathrm{bp}$ encoding for 247 amino acids. The PmOvtra 2 exhibited a predicted RNA-recognition motif (RRM) domain and two arginine-serine (RS) regions, suggesting its function in RNA splicing. The full cDNA sequence of Pmfru-1 consisted of 1,306 with a 1,182 bp ORF encoding for 393 amino acids, whereas the full cDNA sequence of Pmfru-2 consisted of 1,858 bp with 1,437 bp ORF encoding 478 amino acids. The deduced amino acid sequences of Pmfru- 1 and Pmfru-2 exhibited highly conserved domains of Fru proteins, including Broad-complex, Tramtrack and Bric-a-brac (BTB) domain and zinc finger (ZF) domain. In addition, Pmfru-1 and Pmfru-2 were suggestively originated from the same single genomic locus by genomic sequence analysis. Specifically, Pmfru pre-mRNA was alternatively spliced for Pmfru-1 and Pmfru-2 to include mutually exclusive exon 7 and exon 6, respectively. Temporal and spatial expression of PmOvtra 2, Pmfru-1, and Pmfru-2 were also investigated by qPCR. The results showed that all were expressed in early developmental stages with undifferentiated gonad starting from nauplius until post-larvae. The expression of PmOvtra 2 started at nauplius stage and gradually increased from mysis to postlarvae (PL) 1. However, expression of Pmfru-1 was low at nauplii stage and slightly increased from protozoea to PL5, whereas expression of Pmfru-2 maintained at low level from nauplius to 
mysis and then gradually increased at PL stages. Expressions of PmOvtra 2, Pmfru-1, and Pmfru-2 were detected in various tissues including nervous tissue, gill, heart, hepatopancreas, gut, and gonads. Interestingly, sexually dimorphic expression of PmOvtra 2, Pmfru-1, and Pmfru-2 was demonstrated in fully developed gonads in which the ovary showed significantly high expressions than the testis. The great difference in the expression pattern of PmOvtra 2, Pmfru-1, and Pmfru-2 in ovary and testis suggested their roles in the female sex determination in $P$. monodon. 
1 Molecular characterization and expression profiling of transformer 2 and fruitless-like

2 homologs in the black tiger shrimp, Penaeus monodon

4 Prawporn Thaijongrak ${ }^{1,2,3}$, Charoonroj Chotwiwatthanakun ${ }^{1,4}$, Phaivit Laphyai ${ }^{1,2}$, Anuphap

5 Prachumwat ${ }^{1,5}$, Thanapong Kruangkum ${ }^{1,2}$, Prasert Sobhon ${ }^{2}$, Rapeepun Vanichviriyakit $1,2^{*}$

$7{ }^{1}$ Center of Excellence for Shrimp Molecular Biology and Biotechnology (Centex Shrimp),

8 Faculty of Science, Mahidol University, Rama VI Road, Bangkok 10400, Thailand.

$9 \quad 2$ Department of Anatomy, Faculty of Science, Mahidol University, Rama VI Road, Bangkok

10 10400, Thailand.

$11{ }^{3}$ Department of Clinical Sciences and Public Health, Faculty of Veterinary Science, Mahidol

12 University, Phutthamonthon Sai 4 Road, Salaya, Phutthamonthon, Nakhon Pathom 73170,

13 Thailand.

$14{ }^{4}$ Nakhonsawan Campus, Mahidol University, Nakhonsawan 60130, Thailand

$15{ }^{5}$ Aquatic Animal Health Research Team, Integrative Aquaculture Biotechnology Research

16 Group, National Center for Genetic Engineering and Biotechnology (BIOTEC), National Science

17 and Technology Development Agency (NSTDA), Pathum Thani 12120, Thailand.

19 Corresponding author:

20 Dr. Rapeepun Vanichviriyakit

21 Center of Excellence for Shrimp Molecular Biology and Biotechnology (Centex Shrimp),

22 Faculty of Science, Mahidol University, Rama VI Road, Bangkok 10400, Thailand.

23 Email: rapeepun.van@mahidol.edu 


\section{Abstract}

Transformer 2 (tra 2) and fruitless (fru) genes have been proven to play a key role in sex determination pathways in many Arthropods, including insects and crustaceans. In this study, a paralog of $P$. monodon tra 2 (Pmtra 2), P. monodon ovarian associated transformer 2 (PmOvtra 2) and 2 isoforms of P. monodon fruitless-like gene (Pmfru-1 and Pmfru-2) were identified and characterized. The full cDNA sequence of PmOvtra 2 consisted of 1,774 bp with the longest open reading frame (ORF) of $744 \mathrm{bp}$ encoding for 247 amino acids. The PmOvtra 2 exhibited a predicted RNA-recognition motif (RRM) domain and two arginine-serine (RS) regions, suggesting its function in RNA splicing. The full cDNA sequence of Pmfru-1 consisted of 1,306 with a 1,182 bp ORF encoding for 393 amino acids, whereas the full cDNA sequence of Pmfru-2 consisted of 1,858 bp with 1,437 bp ORF encoding 478 amino acids. The deduced amino acid sequences of Pmfru-1 and Pmfru-2 exhibited highly conserved domains of Fru proteins, including Broadcomplex, Tramtrack and Bric-a-brac (BTB) domain and zinc finger (ZF) domain. In addition, Pmfru-1 and Pmfru-2 were suggestively originated from the same single genomic locus by genomic sequence analysis. Specifically, Pmfru pre-mRNA was alternatively spliced for Pmfru-1 and Pmfru-2 to include mutually exclusive exon 7 and exon 6, respectively. Temporal and spatial expression of PmOvtra 2, Pmfru-1, and Pmfru-2 were also investigated by qPCR. The results showed that all were expressed in early developmental stages with undifferentiated gonad starting from nauplius until post-larvae. The expression of PmOvtra 2 started at nauplius stage and gradually increased from mysis to postlarvae (PL) 1. However, expression of Pmfru-1 was low at nauplii stage and slightly increased from protozoea to PL5, whereas expression of Pmfru-2 maintained at low level from nauplius to mysis and then gradually increased at PL stages. Expressions of PmOvtra 2, Pmfru-1, and Pmfru-2 were detected in various tissues including 
47 nervous tissue, gill, heart, hepatopancreas, gut, and gonads. Interestingly, sexually dimorphic

expression of PmOvtra 2, Pmfru-1, and Pmfru-2 was demonstrated in fully developed gonads in which the ovary showed significantly high expressions than the testis. The great difference in the expression pattern of PmOvtra 2, Pmfru-1, and Pmfru-2 in ovary and testis suggested their roles in the female sex determination in P. monodon.

\section{Introduction}

Shrimp farming is a major aquaculture sector in the world that generates high economic value. Penaeus monodon or black tiger shrimp is one of the main aquaculture species widely distributed in the Indo-Pacific region (Flegel, 2012; Mandal et al., 2012). It belongs to the family Penaeidae, which is known for its large size and fast growth rate. In crustacea, many species generally show sexual dimorphism in growth, especially Macrobrachium spp. and Penaeus spp. (Bajaniya, Nair, Salin, \& Tank, 2014; Nogueira et al., 2019). Penaeus monodon also exhibits differential growth rate in which female show superior growth to male. Therefore, culture of allfemale monosex population is highly attractive to increase the production of shrimp $(\mathrm{S}$. Li, Li, Wen, \& Xiang, 2012; Mareddy et al., 2011). Phenotypic differences between male and female is thought to principally result from sex determination and sex differentiation gene expressions (Liu et al., 2015). Therefore, the molecular and genetic pathways of sex determination and sex differentiation in shrimp have been receiving great attention in recent years.

Mechanisms of sex determination in animals have been classified as either environmental sex determination (ESD) or genotypic sex determination (GSD) (Nöthiger \& Steinmann-Zwicky, 1985; Sánchez, 2004). The mechanisms of sex determination in shrimp have been reported to be GSD with ZW sex determination system, in which female are heterogametic (ZW) and male are 
70

71

72

73

74

75

76

77

78

79

80

81

82

83

84

85

86

87

88

89

90

91

92

homogametic (ZZ) (Y. Li et al., 2003; Staelens et al., 2008; Zhang et al., 2007). However, little is known about the pathway of sex determination in penaeid shrimp.

Molecular mechanisms of sex determination in insects have been well characterized. In Drosophila, the primary signal of sex determination is sex lethal (Sxl) protein (Penalva \& Sánchez, 2003). The Sxl protein acts as the master switch that controls female-specific splicing of pre-mRNA of transformer (tra) (Inoue, Hoshijima, Sakamoto, \& Shimura, 1990; Penalva \& Sánchez, 2003). Dimerization of Tra protein and Transformer-2 (Tra-2) protein regulate female sex determination in Drosophila (Nagoshi, McKeown, Burtis, Belote, \& Baker, 1988) but functional Tra is not expressed in males (Boggs, Gregor, Idriss, Belote, \& McKeown, 1987). As a splicing factor, Tra-2 consists of RNA-recognition motif (RRM) domain and two arginineserine (RS) regions. The Tra and Tra-2 heterodimer functions in sex-specific alternative splicing of downstream RNA including doublesex (dsx) and fruitless (fru) (Heinrichs, Ryner, \& Baker, 1998; Inoue, Hoshijima, Higuchi, Sakamoto, \& Shimura, 1992; Penalva \& Sánchez, 2003;

Pomiankowski, Nöthiger, \& Wilkins, 2004). The Dsx and Fru proteins act as transcription factors which control development of sex-specific differences in many insects (Pomiankowski et al., 2004). The $d s x$ is also involved in somatic sex differentiation and some aspect of sex behavior (Burtis \& Baker, 1989; Christiansen, Keisman, Ahmad, \& Baker, 2002; Pomiankowski et al., 2004). The fru plays a critical role in male courtship behavior and sex-nonspecific developmental functions (Dauwalder, 2011; Demir \& Dickson, 2005; P. Li, Liu, Luo, Song, \& Cui, 2017). The fru is a multifunctional gene having a complex coordination of 4 promoters and alternative splicing which can encode several isoforms of fru (Dalton et al., 2013). All fru isoforms exhibit Broad-complex, Tramtrack and Bric-a-brac (BTB) domain and zinc finger (ZF) domain. The BTB domain serves as a protein-protein interaction module, whereas the ZF domain 
93 serves as DNA-binding motif (Salvemini et al., 2013; Zollman, Godt, Prive, Couderc, \& Laski, 94 1994).

Several insect homologs of sex determining genes have been identified and characterized

96 in many decapod crustaceans such as P. vannamei ( $s x l)$ (López-Cuadros et al., 2018),

97 Macrobrachium nipponense (sxl 1 and sxl 2) (YP Zhang et al., 2013), P. monodon (tra 2)

98 (Leelatanawit et al., 2009), P. chinensis (tra 2) (S Li et al., 2012), Scylla paramamosain (tra 2)

99 (Wang et al., 2020), Palaemon serratus (tra 2) (González-Castellano, Manfrin, Pallavicini, \&

100 Martínez-Lage, 2019), Sagmariasus verreauxi (tra 2) (Chandler, Aizen, Elizur, Battaglene, \&

101 Ventura, 2015), Eriocheir sinensis (tra 2) (Luo et al., 2017), Daphnia magna (dsx) (Kato,

102 Kobayashi, Watanabe, \& Iguchi, 2011), and E. sinensis (frul and fru2) (P. Li et al., 2017). Most

103 of sex determining genes identified in crustaceans displays high sequence similarity with

104 their homologs in insects. In addition, homolog of Caenorhabditis elegans sex determining

105 gene feminization-1 (fem- 1 ) has been reported in P. vannamei and P. monodon (Galindo-Torres,

106 Ventura-López, Llera-Herrera, \& Ibarra, 2019; Robinson et al., 2014). However, functions of sex

107 determining genes in many crustaceans have not been investigated.

108

In this study, we identified and characterized sex determining homologs in P. monodon

including ovarian associated transformer 2 (PmOvtra 2), and 2 isoforms of fruitless-like gene

110

(Pmfru-1 and Pmfru-2). Moreover, their temporal and spatial expression profiles were

111

investigated. All of them showed sexually dimorphic expression patterns in gonadal tissues.

112 Dominant expressions of PmOvtra 2, Pmfru-1, and Pmfru-2 were shown in ovarian tissue,

113 suggesting their role in female-sex determination in this species.

\section{Materials and methods}




\subsection{Nucleotide sequences and deduced amino acid sequences analyses}

117 Nucleotide sequences of P. monodon candidate sex determining genes PmOvtra 2, Pmfru-1

118

119

120

121

122

123

124

125

126

127

128

129

130

131

132

133

134

135

136

137

138

and Pmfru-2 were obtained from our transcriptome data prepared from P. monodon central nervous tissue (unpublished data). The nucleotide and deduced amino acid sequences of the putative sex determining genes were analyzed with Expasy Translate tool (Gasteiger et al., 2003) (https://web.expasy.org/translate/) for open reading frame (ORF), Compute pI/MW tool (https://web.expasy.org/compute_pi/) for molecular weight (MW) and isoelectric point (pI) and Simple Modular Architecture Research Tool GENOMES (Letunic, Khedkar, \& Bork, 2021) (http://smart.embl-heidelberg.de/smart/set_mode.cgi? GENOMIC=1) for functional protein domains. Homologous amino acid sequences in other crustaceans and arthropods (Tables 1 and 2) were obtained from NCBI GenBank database with literature and BLAST searches (https://blast.ncbi.nlm.nih.gov/). Selected species included in the analyses were those in evolutionary lineages leading to P. monodon and with putative orthologs of Pmtra 2, PmOvtra 2, Pmfru-1 and Pmfru-2 proteins, and their homologs/orthologs copies were either functionally characterized in other species (literature searches) or with highest sequence similarity to the corresponding homologs of interest in P. monodon (BLAST searches). Multiple sequence alignments of the homologous amino acid sequences of Tra 2 and Fru gene sets were separately performed with MAFFT version 7 web service (Katoh, Rozewicki, \& Yamada, 2019) with a default setting (https://mafft.cbrc.jp/), the best substitution model for each protein sequence set was obtained with ProtTest 3 (version 3.4.2) (Darriba et al., 2011), and the phylogenetic trees were performed with RAxML (version 8.2.12; (Stamatakis, 2014)) with 1,000 bootstrapping. Tra 2 phylogenetic tree was constructed with a GAMMA model of rate heterogeneity and the WAG substitution model with empirical amino acid frequencies, but Fru phylogenetic tree was 
139 constructed with a GAMMA model of rate heterogeneity and the VT substitution model with 140 empirical amino acid frequencies.

141

142

143

144

145

146

147

148

149

150

151

152

153

154

155

156

157

158

159

160

\subsection{Animal and tissue sampling}

Male and female $P$. monodon broodstocks were obtained from Shrimp Genetic infections, i.e., White spot syndrome virus (WSSV), Yellow head virus (YHV), Taura syndrome virus (TSV), Monodon baculovirus (MBV), P. monodon densovirus (PmDNV), Infectious hypodermal and hematopoietic necrosis virus (IHHNV), Decapod iridescent virus 1 (DIV1) and Vibrio parahaemolyticus. Shrimp were acclimatized in $1000 \mathrm{~L}$ artificial seawater (30-35 ppt) in fiberglass tanks with constant aeration. The water temperature was maintained at $28 \pm 2{ }^{\circ} \mathrm{C}$. Shrimp were fed with commercial pellets, three times a day. Shrimp were euthanized by ice water immersion before tissue collection. A variety of tissues, including eyestalk, nervous tissue, gill, hepatopancreas, heart, gastrointestinal tract, testis and ovary were collected from female and male shrimp. The tissue samples were immediately kept in Tri-Reagent ${ }^{\circledR}$ (MRC, USA) and stored at $-80^{\circ} \mathrm{C}$ until used. In addition, various developmental stages of larvae, including nauplii, protozoea, mysis, and postlarvae, were obtained from SGIC. Samples were collected, washed with Phosphate buffered saline (PBS), and preserved in $1 \mathrm{ml}$ of Tri-Reagent ${ }^{\circledR}$ solution and stored at $-80^{\circ} \mathrm{C}$ until used. All animals experiment was approved by the Animal Ethics Committee, Faculty of Science, Mahidol University (MUSC63-019-527).

\subsection{RNA extraction and cDNA synthesis}


manufacturer's instruction. Briefly, the tissue samples were homogenized in Tri-Reagent $\mathbb{R}$

solution and incubated at room temperature for $5 \mathrm{~min}$. Homogeneous mixture was subjected to

chloroform extraction and the total RNA was precipitated with isopropanol. The RNA pellet

167 (ThermoScientific, USA). For cDNA synthesis, DNaseI was used to remove genomic DNA in

reverse transcription reaction which consisted of Random hexamer (Invitrogen, USA) and according to the manufacturer's instructions. All cDNA samples were stored at $-80^{\circ} \mathrm{C}$ until used.

\section{Reverse transcription polymerase chain reaction (RT-PCR)}

Shrimp tissues, including eyestalk, nervous tissue, gill, hepatopancreas, heart, gastrointestinal tract, testis and ovary were collected from six healthy adult shrimp. Pooled samples were prepared for RT-PCR analysis. Expression patterns of PmOvtra 2, Pmfru-1 and Pmfru-2 in various tissues of adult males and females were investigated by RT-PCR. The specific primers were designed and shown in Table 3, and $16 s r R N A$ was used as housekeeping gene. Reverse transcription PCR master-mix included cDNA template, 10x PCR buffer, $10 \mu \mathrm{M}$ of forward primer and reverse primer, $10 \mathrm{mM} \mathrm{dNTP,} 2.5 \mathrm{U}$ of Taq DNA polymerase (Invitrogen, 
184 USA) and DEPC treated sterile distilled water. The amplifications were carried out using 185 temperature cycling conditions as follows: 1 cycle of $94^{\circ} \mathrm{C}$ for 5 mins; 35 cycles of $94^{\circ} \mathrm{C}$ for $30 \mathrm{~s}$, $18655^{\circ} \mathrm{C}$ for $30 \mathrm{~s}$ and $72^{\circ} \mathrm{C}$ for $45 \mathrm{~s} ; 1$ cycle of $72^{\circ} \mathrm{C}$ for $10 \mathrm{~min}$. The PCR products were resolved by $187 \quad 1.5 \%$ agarose gel electrophoresis.

188

189

190

191

192 193

\subsection{Quantitative real-time PCR (qPCR)}

Developmental stages of larvae, including nauplii, protozoea, mysis, and postlarvae were collected and approximately 30 individuals in the same stage were pooled as one sample.

Ovaries and testes were collected from 5 adult females and 5 adult males, and each was run as individual sample. Three replicates were prepared for each sample. Quantitative real-time PCR was performed in 96-well plates in a final volume of $20 \mu 1$. Each reaction contained $2 \mu \mathrm{l}$ of cDNA, $10 \mu \mathrm{l}$ of KAPA SYBR®FAST qPCR Master-Mix (2X) (KAPA Biosystems), $0.4 \mu \mathrm{l}$ of specific forward and reverse primers $(10 \mu \mathrm{M} / \mu \mathrm{l})($ List of specific primers are shown in the Table 3), and 7.2 $\mu$ of DEPC treated sterile distilled water. The reaction was carried out in the 7500 Real Time PCR system (Applied Biosystems) with the following qPCR conditions: initial denaturing at $95{ }^{\circ} \mathrm{C}$ for $3 \mathrm{~min} ; 40$ cycles of $95^{\circ} \mathrm{C}$ for $3 \mathrm{~s}, 60^{\circ} \mathrm{C}$ for $30 \mathrm{~s}$, and $72{ }^{\circ} \mathrm{C}$ for $30 \mathrm{~s}$ and finally, 1 cycle of $95{ }^{\circ} \mathrm{C}$ for $15 \mathrm{~s}, 60^{\circ} \mathrm{C}$ for $1 \mathrm{~min}, 95^{\circ} \mathrm{C}$ for $30 \mathrm{~s}, 60^{\circ} \mathrm{C}$ for $15 \mathrm{~s}$. The production of specific products was confirmed by performing a melting curve analysis of the samples. The reaction without cDNA was used as the negative control. The same qPCR profile was performed for $16 \mathrm{~s} r N A$ amplification which served as a reference gene. To confirm that $16 \mathrm{~s} r N A$ was qualified as a reference gene used, the stability of $16 \operatorname{sinNA}$ EF1- $\alpha$, and $\beta$-actin, was evaluated in the samples. The result suggested that $16 s r R N A$ would be one of the versatile reference genes for this assay (Supplement 3 and 4). Data were analyzed with 7500 software v.2.3 (Applied 
207 Biosystems). The baseline was set automatically by the software to maintain consistency. The

208 comparative CT method ( $2^{-\Delta \Delta \mathrm{CT}}$ method) was performed for analyze the expression levels of

209 PmOvtra 2, Pmfru-1 and Pmfru-2 (Livak \& Schmittgen, 2001).

$210 \quad$ 2.6. $\quad$ Statistical Analysis

211 Data represented the mean \pm standard deviation (S.D.). Statistical analysis was performed

212 using Graph-Pad Prism 5 software (Motulsky, 2007). Statistical significance between two groups

213 (testis and ovary) were determined using unpaired t-test. Significant difference was considered at

$214 P<0.01$. Statistical significance between groups of larvae developmental stages was determined

215 using Tukey's multiple comparison tests and one-way ANOVA. Significant difference was

216 considered at $p<0.05$.

217

218

219

220

The full-length cDNA sequence of $P$. monodon ovary associated transformer 2 (PmOvtra

2) and two isoforms of P. monodon fruitless-like gene (Pmfru-1 and Pmfru-2) were obtained from our transcriptome database. PmOvtra 2 (GenBank Acc. No. MT543028) included 1,774 nt. with 110 bp 5'-untranslated region (UTR), a 744 bp open reading frame (ORF) and 920 bp 3'UTR (supplement 1). The putative amino acid sequences analyses of PmOvtra 2 showed that PmOvtra 2 was comprised of 247 amino acids with predicted molecular weight of $28.41 \mathrm{kDa}$ and the theoretical isoelectric point was 11.34. PmOvtra 2 contained a predicted RRM domain and two RS regions that were highly conserved among Tra 2 proteins in several species. The predicted RRM domain of PmOvtra 2 was located at $101-180$ aa (Figure 1). 

2 (GenBank Acc. No. MT503286) were 1306 and 1858 bp, respectively. Pmfru-1 consisted of a

231

232

233

234

235

236

237

238

239

240

241

242

243

244

245

246

247

$101 \mathrm{bp}$ 5'-UTR, a 1,182 bp ORF and a 23 bp 3'-UTR. The cDNA sequence of Pmfru-2 consisted of a 92 bp 5'-UTR, a 1,437 bp ORF and a 329 bp 3'-UTR (Supplement 2). The putative amino acid sequences of Pmfru-1 comprised of 393 amino acids with predicted molecular weight of $43.93 \mathrm{kDa}$, whereas the Pmfru-2 comprised of 478 amino acids with predicted molecular weight of 52.41 kDa. The theoretical isoelectric points of Pmfru-1 and Pmfru-2 were 5.38 and 5.56, respectively. Translated amino acid sequences of both Pmfru-1 and Pmfru-2 contained BTB domain with zinc finger domain which were highly conserved in Fru proteins in several insect and crustacean species. The BTB domain and zinc finger domain of Pmfru-1 were located at 31126 aa and 339-389 aa, respectively, while that of Pmfru-2 were at 31-126 aa and 373-395 / 401424 aa (Figure 2).

\subsection{Multiple sequence alignments and phylogenic analysis of PmOvtra 2, Pmfru-}

\section{1 and Pmfru-2}

Due to evolutionary complexity of Tra 2 and Fruitless protein families, we focused on analyzing amino acid sequences of Pmtra 2, PmOvtra 2, Pmfru-1 and Pmfru-2 in P. monodon and of their homologs/orthologs (see Tables 1 and 2) in other species. Other putative paralogous proteins annotated in a draft genome sequence of $P$. monodon were not included because in this study we sought to infer evolutionary scenarios of Pmtra 2, PmOvtra 2, Pmfru-1 and Pmfru-2 but not of all paralogs in these two protein families (see Materials and Methods).

Tra 2 phylogenetic tree from maximum likelihood analyses of Tra 2 amino acid sequences (Figure 3) revealed two distinct sister subclades of PmOvtra 2 and Pmtra 2 with their 
252 corresponding homologous sequences in the other crustaceans, and these two subclades

253 containing PmOvtra 2 and Pmtra 2 formed a clade that was separated from D. melanogaster

254 homolog (bootstrap re-sampling value 100\%). The PmOvtra 2 and Pmtra 2 topology in the Tra 2

255 phylogenetic tree (Figure 3) suggests that they were paralogous and duplicated in the last

256 common ancestor of crustaceans. We named the two sister subclades containing PmOvtra 2 and

257 Pmtra 2 paralogs as the PmOvtra 2 and Pmtra 2 clades, respectively (Figure 3). Based on Tra 2

258 multiple amino acid sequence alignment analyses, PmOvtra 2 had higher percentage amino acid

259 identities to the other previously reported Tra 2 orthologs in crustaceans within the PmOvtra 2

260 clade $(98.68 \%, 89.47 \%, 86.18 \%$ and $86.18 \%$ to $P$. chinensis, C. quadricarinatus, M. rosenbergii

261 and M. nipponense, respectively) than to the previously characterized paralog Pmtra $2(62.83 \%)$.

262 Both PmOvtra 2 and Pmtra 2 had a high percentage amino acid identity $(98.68 \%$ and 99.32\%,

263 respectively) to their putative ortholog in the $P$. vannamei draft genome. Similarly, for the

264 conserved RRM domain (80 residues), PmOvtra 2 had a higher percentage identity to its

265 orthologs in P. chinensis (98.75\%), P. vannamei (98.75\%) and C. quadricarinatus (92.50\%) than

266 to the paralog Pmtra 2 (70\%). Note that similar percentage amino acid identities to the well-

267 characterized insect D. melanogaster ortholog (264 residues) were observed for both PmOvtra 2

268 (51.97\%) and Pmtra 2 (48.64\%).

269 A maximum likelihood phylogenetic tree (Figure 4) of Pmfru-1 and Pmfru-2 protein

270 homologs (Table 2) placed both Pmfru-1 and Pmfru-2 with a copy in P. vannamei (bootstrap re-

271 sampling value 100\%) and in turn placed this clade of three proteins as a sister clade of another

272 clade containing previously characterized Fru proteins in E. sinensis and insects, e.g., Fru in $D$.

273 melanogaster (bootstrap re-sampling value 85\%). Such a placement of Pmfru-1 and Pmfru-2 in

274 the phylogenetic tree suggested that the genomic locus (see below) of Pmfru-1 and Pmfru-2 was 
275 orthologous to that of a putative Fru copy in $P$. vannamei and had an evolutionary relationship

276 with other previously characterized fruitless in E. sinensis and insects. Based on Fru multiple

277 amino acid sequence alignment analyses, Pmfru-1 and Pmfru-2 had 99.31\% amino acid identity

278 to putative P. vannamei Fru copy, but $26.3 \%$ to E. sinensis Fru copy, the only characterized copy

279 in crustacean so far. Interestingly, Pmfru-1 and Pmfru-2 had 38.1-43.6\% amino acid identities to

280 those well-characterized copies in insects. The BTB domain sequences of Pmfru-1 and Pmfru-2

281 were identical (100\% identity due to the identical nucleotide sequences in the region; see

282 Supplementary alignment 2), and they were also identical to that of $P$. vannamei (Figure 2). They

283 had $46.80 \%, 43.61 \%$ and $41.48 \%$ identity with that of $N$. vitripennis, D. melanogaster and $A$.

284 aegypti, respectively, but they had $27.65 \%$ to that of E. sinensis Fru copy. Contrary to the BTB

285 domain, the ZF domain sequences of Pmfru-1 and Pmfru-2 shared only $26.31 \%$ identity. Pmfru-1

286 ZF domain sequences had a lower sequence identity to those of D. melanogaster, A. aegypti and

287 N. vitripennis than did Pmfru-2 (28.94 vs. $31.57 \%$, 28.94 vs. $31.57 \%$ and 23.68 vs. $31.57 \%$,

288 respectively). It should be noted that $\mathrm{ZF}$ domains were not predicted for the protein sequences of

289 P. vannamei and E. sinensis.

290

291

292

3.3. Gene organization and alternative splicing of Pmfru-1 and Pmfru-2

293

294

295

296

297

Since nucleotide sequences of Pmfru-1 and Pmfru-2 share identical sequences between

11-1109 nt of Pmfru-1 and 2-1100 nt of Pmfru-2 (see Supplementary alignment 2), we sought to determine whether Pmfru-1 and Pmfru-2 are results of alternative splicing events by searching the nucleotide sequences against a draft genomic sequence of P. monodon. Both Pmfru-1 and Pmfru-2 were aligned by BLASTN to only a single scaffold sequence (Accession number NC_051415.1 or PmonScaffold_30) and formed seven interval regions as putative seven exons 
298

299

300

301

302

303

304

305

306

307

308

309

310

311

312

313

314

315

316

317

318

319

of $87,95,594,243,90,761$ and 197 bp in length, respectively (Figure 5). Five out of the seven exons showed the identical sequences between sequences of Pmfru-1, Pmfru-2 and genomic scaffold sequences, whereas the other two (exons 3 and 6) each had one mismatched base-pair ( $\geq$ 99.7\% identity) to the genomic scaffold sequence. At these exon-intron junctions, splice dinucleotide sequences of GT donor sites and AG acceptor sites are observed. The result suggested that Pmfru-1 and Pmfru-2 were likely produced by constitutive splicing events of exons 1 to 5 and alternative splicing events of exon 6 to Pmfru-2 mature mRNA and exon 7 to Pmfru-1 mature mRNA (i.e., mutually exclusive exons; Figure 5). The start codons (ATG) of Pmfru-1 and Pmfru-2 were both located in exon 2, whereas the stop codons (TGA) of Pmfru-1 and Pmfru-2 were located in exon 7 and exon 6, respectively.

\subsection{Temporal expression profiles of PmOvtra 2, Pmfru-1 and Pmfru-2}

The temporal expressions of PmOvtra 2, Pmfru-1 and Pmfru-2 were determined by qPCR. The specific primers were designed and shown in Table 3. The relative expression levels of PmOvtra 2, Pmfru-1 and Pmfru-2 were determined in different developmental stages of larvae and post-larvae, including nauplius, protozoea, mysis, and post-larvae stage 1, 5, 10, and 15 (PL1, PL5, PL10, and PL15). PmOvtra 2, Pmfru-1 and Pmfru-2 mRNA expression levels were normalized to the 16s rRNA transcript level. The results showed that PmOvtra 2 was detected in all the developmental stages of P. monodon. Notably, PmOvtra 2 expression was relatively low in nauplius and protozoea stages, and then gradually increased from mysis to PL1. The PmOvtra 2 expression level reached the highest level in PL1 but it abruptly decreased from PL5 to PL15 (Figure 6A). 
The Pmfru-1 and Pmfru-2 transcripts were detected in all larval stages of P. monodon.

321 The Pmfru-1 transcripts showed low expression levels at nauplii stage and slightly increased

322 from protozoea to PL5. The Pmfru-1 expression level reached the highest level at PL1 and

323 gradually decreased from PL10 to PL15 (Figure 6B). The Pmfru-2 expression level maintained a

324 low level from nauplius to mysis and then gradually increased at the postlarval stages. The

325 Pmfru-2 expression level reached high level in PL1 and then gradually decreased at PL5. The

326 Pmfru-2 transcripts also increased at PL10 and reached the highest levels at PL15 (Figure 6C).

327

328

329

330

331

332

333

334

335

336

337

338

339

340

341

342

3.5. Tissue distribution of PmOvtra 2, Pmfru-1 and Pmfru-2 in adult P. monodon

Expression of PmOvtra 2, Pmfru-1, and Pmfru-2 transcripts were determined by RT-

PCR in several tissues, including eyestalks, nervous tissues, gill, hepatopancreas, heart, gastrointestinal tract, and gonads. Expression of 16s rRNA, showing the band at $152 \mathrm{bp}$, was utilized as internal control. The expression of PmOvtra 2, which exhibited the specific band at $449 \mathrm{bp}$, showed in nervous tissues, gill, heart, gastrointestinal tract, testis and ovary (Figure 7). Apparently, the expression of PmOvtra 2 was high in ovary compared with other tissues.

Expression of Pmfru-1 exhibited the specific band at 262 bp. Reverse transcription PCR results showed that Pmfru-1 was expressed in several tissue, i.e., eyestalk, nervous tissues, gill, hepatopancreas, heart, gastrointestinal tract, testis and ovary (Figure 7). Notably, the band of Pmfru-1 expression was intense in gonadal tissues, both testis and ovary. It was suggested that the gonad tissue might be a major organ for Pmfru-1 mRNA expression. Regarding the expression of Pmfru-2, its expression exhibited the specific band at $345 \mathrm{bp}$. The result showed the expression of Pmfru-2 in eyestalks, nervous tissues, gill, hepatopancreas, heart, gastrointestinal tract, and gonad, with high preference for ovary (Figure 7). 
344 shown by RT-PCR, the expression patterns of these genes in testes and ovaries were further

345 quantified by qPCR to see whether their expressions were different between sexes of $P$.

346 monodon. The expression patterns of PmOvtra 2, Pmfru-1, and Pmfru-2 in testes and ovaries

347 were normalized to the 16s rRNA transcript level. Relative expressions of PmOvtra 2, Pmfru-1,

348 and Pmfru-2 in the ovary were $26.37 \pm 10.64,71.27 \pm 42.92$, and $60.99 \pm 29.45$, respectively.

349 However, the relative expressions of these transcripts in the testis were much lower, i.e., $1.20 \pm$

$3500.41,0.99 \pm 0.26$ and $1.40 \pm 0.68$, respectively. The result indicated significantly higher

351 expression of PmOvtra 2, Pmfru-1, and Pmfru-2 in the ovary compared with the testis $(p<0.01)$

352 (Figure 8).

353

354

4. Discussion

355

This study identified and characterized putative sex determining genes in P. monodon, including PmOvtra 2, Pmfru-1, and Pmfru-2. Transformer 2 has been reported as a key gene for sex determination in some insects and crustaceans by regulating RNA splicing (Cai et al., 2020). Transformer 2 protein forms a heterodimer with Tra protein and acts as a splicing factor on downstream RNA that requires sex-specific splicing (Nöthiger \& Steinmann-Zwicky, 1985). The direct targets of Tra 2 and Tra heterodimer include doublesex (dsx) and fruitless (fru) (Haag \& Doty, 2005). In fact, P. monodon transformer 2 (Pmtra 2; GenBank accession no. ACD13597) has previously been reported. In this study, a newly identified paralog of Pmtra 2 in P. monodon was characterized and designated as $P$. monodon ovarian associated tra 2 (PmOvtra 2) due to its one RRM and two RS domains with Tra 2 proteins in insects and crustaceans (Figure 1) (Haag \& 
366 Doty, 2005; Yanping Zhang et al., 2013). Our maximum likelihood phylogenetic tree of Tra 2 367 suggests the duplication event of PmOvtra 2 and the previously reported Pmtra 2 (Leelatanawit et 368 al., 2009) most likely in the last common ancestor of crustaceans (Figure 3), and each had its own 369 orthologous sequences in almost all crustacean species with publicly available genomic sequences. Indeed, PmOvtra 2 and Pmtra 2 were found to be located on two different genomic loci/scaffolds in the draft $P$. monodon genome sequence, and they had different orthologs in P. vannamei (Table 1 and Figure 3). Based on the amino acid sequence alignment, a higher similarity of either PmOvtra 2 or Pmtra 2 to their corresponding crustacean orthologs, for examples in P. vannamei (98.68\% and 99.32\%, respectively), than between PmOvtra 2 and Pmtra 2 (62.83\%) also supports the duplication event of the two genes in the crustacean last common ancestor. Moreover, our maximum likelihood phylogenetic tree of Tra 2 suggests that the previously reported Tra 2 in $P$. chinensis, C. quadricarinatus, $M$. rosenbergii and M. nipponense were orthologs of PmOvtra 2, and the previously reported Tra 2 in E. sinensis and S. paramamosain were orthologs of Pmtra 2 (Figure 3). Note that gene names given to these previously characterized orthologs in crustacean species in each clades are varied, e.g., the PmOvtra 2 clade contains Tra $2 a$ and Tra $2 b$, and the

Pmtra 2 clade contains Tra 2 and Tra 2c. Further studies are needed to characterize all paralogs in these crustacean genomes.

Fruitless gene is one of the key genes in sex determination in insects (Bertossa, van de factors BTB-Zn-finger, which represents a group of transcription factors (Drapeau, Radovic, discovered two fruitless-like homologs, namely Pmfru-1 and Pmfru-2, in shrimp for the first time. 
389 domains. Fruitless have been identified in several insect and crustacean species, including many

390 species in Drosophilidae, Nasonia vitripennis, Gryllus bimaculatus, and Chinese mitten crab E.

391 sinensis (Bertossa et al., 2009; P. Li et al., 2017; Ryner et al., 1996; Watanabe, 2019; Zollman et

392 al., 1994). We showed that Pmfru-1 and Pmfru-2 could be derived from the same genomic locus

393 by mutually-exclusive-exons alternative splicing of the Pmfru pre-mRNA (Figure 5). The two

394 isoforms Pmfru-1 and Pmfru-2 were orthologous to a sequence in P. vannamei draft genome

395 sequence with $99.31 \%$ amino acid identity. Based on our maximum likelihood phylogenetic tree

396 analyses, the clade of Pmfru-1 and Pmfru-2 isoforms and their P. vannamei ortholog was clustered

397 to the clade containing previously characterized Fru in D. melanogaster, N. vitripennis, and

398 Chinese mitten crab E. sinensis (Figure 4). Thus, the locus of Pmfru-1 and Pmfru-2 isoforms was

399 conserved in penaeid shrimp, but its evolutionary relationship to the previously characterized

400 fruitless in Chinese mitten crab E. sinensis needs to be further investigated since the placement of

401 the two sister clades was supported by the bootstrap re-sampling value $85 \%$ (Figure 4 ). Note that

402 the current draft genome sequence of $P$. monodon contains other putatively annotated paralogs of

403 fruitless (e.g., on scaffolds NC_051406.1, NC_051418.1, NC_051427.1 and NC_051428.1).

404 These genomic regions are different genomic regions from the region that was aligned with Pmfru-

4051 and Pmfru-2 isoforms on scaffold NC_051415.1 and that was putatively annotated for ORF of

406 several longitudinals lacking protein isoforms. Evolutionary relationships and functional

407 characterization among all paralogs of the BTB family proteins in $P$. monodon should be further

408 investigated.

409 Functions of genes are commonly related to the pattern of gene expression. Therefore, the

410 temporal and spatial expression of PmOvtra 2, Pmfru-1, and Pmfru-2 transcripts were analyzed

411 in this study. In our study, $16 s \mathrm{r} R A$ was used as an internal control gene in RT-PCR and qPCR 
412 assay (Chotwiwatthanakun et al., 2016; Chotwiwatthanakun et al., 2018). A study on reference 413 genes for qPCR in P. monodon has suggested that EF1- $\alpha$ would be more versatile as a reference 414 gene in reproductive organs (Leelatanawit et al., 2012). However, evaluation in our samples 415 showed that $16 \mathrm{~s} r R A$ and $\beta$-actin expressions in gonads were relatively stable (Supplement 3 ).

416 Therefore, in this study, 16s $r R N A$ was used as an internal control gene in both gonads sample 417 and various larvae and post-larvae development stages. Expression of PmOvtra 2 was detected in 418 all the developmental stages of $P$. monodon starting from nauplius stage and it gradually 419 increased from mysis to PL1 stages. Moreover, Pmfru-1 transcripts showed low expression at 420 nauplii stage and slightly increased from protozoea to PL5. The Pmfru-2 expression level maintained at low level from nauplius to mysis and then gradually increased at the postlarval 422 stages. Basically, genes involved in sex determination are expressed early during development 423 before the appearance of genital organs. In P. vannamei, the genital organs, testis and ovary, are 424 fully detected at 16 days post-larvae stage (Garza-Torres, Campos-Ramos, \& Maeda-Martínez, 2009). However, the differentiation of external gonad, including thelycum and gonopores, requires more time and they can be recognized around 50 days post-larvae stage (Garza-Torres et 427 al., 2009). In P. japonicus, the male reproductive organs, i.e., testis, vas deferens and ejaculatory 428 bulb, can be detected at 20 days post-larvae stage (Nakamura, Matsuzaki, \& Yonekura, 1992). In 429 P. chinensis, the differentiation of gonad cannot be discriminated before PL76 (S. Li et al., 2012). 430 In this study, PmOvtra 2, Pmfru-1 and Pmfru-2 transcripts could be detected at a very early stage of development which was earlier than the differentiation of gonad in Penaeus spp. rather than sex-specifically alternative splicing (S Li et al., 2012; Shihao Li, Li, Yu, \& Xiang, 2018; Liu et al., 2015). Dimorphic expression of many sex determination genes in gonads of 
435 crustaceans have also been reported, e.g., Pmtra 2 in P. monodon (Leelatanawit et. al., 2009), tra

4362 in P. chinensis, S. paramamosain, E. sinensis (S Li et al., 2012; Luo et al., 2017; Wang et al.,

437 2020), fru in E. sinensis (P. Li et al., 2017), $d s x$ in D. magna (Kato et al., 2011), sxl in $P$.

438 vannamei and M. nipponense (López-Cuadros et al., 2018; YP Zhang et al., 2013). This study

439 also showed sexually dimorphic expression patterns of PmOvtra 2, Pmfru 1, and Pmfru 2 genes

440 in fully developed gonads. Notably, expression of PmOvtra 2 in the ovary was greatly higher

441 when compared with the testis of $P$. monodon, suggesting possible function of PmOvtra 2 in the

442 female sex determination pathway. The dominant expression of PmOvtra 2 in ovary was similar

443 to that of Fctra-2c in P. chinensis which was reported to be involved in female sex determination

444 (S Li et al., 2012). In contrast, in M. nipponense, Mntra 2 was suggested to be involved in male

445 sex determination as it displayed significantly higher expression level in testis than ovary

446 (Yanping Zhang et al., 2013). In S. paramamosain, Sptra 2 was also highly expressed in several

447 tissues of male crabs, suggesting its role male sex determination system (Wang et al., 2020). In

448 Chinese mitten crab E. sinensis, alternatively splicing of tra 2, Estra-2a and Estra-2c, has been

449 reported and suggested to play role in male and female sex determination system, respectively

450 (Luo et al., 2017). Role of tra 2 in sex determination appears to be diverse in different species.

451 In P. monodon, specific roles of PmOvtra 2 in sex determination and ovary development need to

452 be verified in further investigation.

453 In this research, we showed that expression of Pmfru-1 and Pmfru-2 was sexually

454 dimorphic in the fully developed gonads. In adult male and female $P$. monodon, the expression

455 levels of Pmfru-1 and Pmfru-2 in ovary was greatly higher than that in testis, suggesting the

456 possible function in female sex determination pathway. Similarly, in E. sinensis, Esfrul expression

457 has been shown particularly in ovary, suggesting its possible function in female sex determination 
458 (P. Li et al., 2017). In contrast to D. melanogaster, Fru proteins play role in the determination of 459 male sexual behavior (Dauwalder, 2011; Gailey \& Hall, 1989; Ryner et al., 1996; Salvemini, 460 Polito, \& Saccone, 2010; Yamamoto, 2008).

461

462

463

\section{Conclusion}

In conclusion, this was the first time to report the existence of fruitless-like homologs in 464

shrimp, i.e., Pmfru-1 and Pmfru-2, and also another paralog of tra 2 in P. monodon, PmOvtra 2.

466

467

468

469

470

471

472

473

474

475

476

477

478
All of them were greatly expressed in the ovary of $P$. monodon. These sexually dimorphic expression patterns in gonadal tissues suggested that PmOvtra 2, Pmfru-1 and Pmfru-2 may be involved in female-sex determination in this species. However, detailed mechanism of sex determination in shrimp remains to be investigated.

\section{References}

Amrein, H., Gorman, M., \& Nöthiger, R. (1988). The sex-determining gene tra-2 of Drosophila encodes a putative RNA binding protein. Cell, 55(6), 1025-1035.

Bajaniya, V. C., Nair, C. M., Salin, K., \& Tank, K. V. (2014). Growth and Survival of Penaeus monodon (Fabricius, 1798) in Monosex and Mixed-sex Cultures. Fishery Technology, 51(1).

Beil, B., Screaton, G., \& Stamm, S. (1997). Molecular cloning of htra2-beta-1 and htra2-beta-2, two human homologs of tra-2 generated by alternative splicing. DNA and cell biology, 16(6), 679690. 
479 Bertossa, R. C., van de Zande, L., \& Beukeboom, L. W. (2009). The Fruitless gene in Nasonia displays complex sex-specific splicing and contains new zinc finger domains. Molecular biology and evolution, 26(7), 1557-1569.

482

483

484

485

486

487

488

489

490

491

492

493

494

495

496

497

498

499

500

501
Boggs, R. T., Gregor, P., Idriss, S., Belote, J. M., \& McKeown, M. (1987). Regulation of sexual differentiation in D. melanogaster via alternative splicing of RNA from the transformer gene. Cell, 50(5), 739-747.

Burtis, K. C., \& Baker, B. S. (1989). Drosophila doublesex gene controls somatic sexual differentiation by producing alternatively spliced mRNAs encoding related sex-specific polypeptides. Cell, 56(6), 997-1010.

Cai, L., Zheng, J., Jia, Y., Gu, Z., Liu, S., Chi, M., \& Cheng, S. (2020). Molecular characterization and expression profiling of three Transformer-2 splice isoforms in the redclaw crayfish, Cherax quadricarinatus. Frontiers in Physiology, 11.

Chandler, J. C., Aizen, J., Elizur, A., Battaglene, S. C., \& Ventura, T. (2015). Male sexual development and the androgenic gland: novel insights through the de novo assembled transcriptome of the eastern spiny lobster, Sagmariasus verreauxi. Sexual Development, 9(6), 338354.Chotwiwatthanakun, C., Sangatit, J., Santimanawong, W., Surinlert, P., Prommoon, J.,Weerachatyanukul, W., Vanichviriyakit, R. (2016). Expression of Penaeus monodon ortholog of Niemann-Pick type C-2 in the spermatic tract, and its role in sperm cholesterol removal. Molecular reproduction and development, 83(3), 259-270.

Chotwiwatthanakun, C., Santimanawong, W., Sobhon, P., Wongtripop, S., \& Vanichviriyakit, R. (2018). Inhibitory effect of a reproductive-related serpin on sperm trypsin-like activity implicates its role in sperm maturation of Penaeus monodon. Molecular reproduction and development, 85(3), 205-214.

PeerJ reviewing PDF | (2021:05:60965:4:1:NEW 24 Jan 2022) 
502 Christiansen, A. E., Keisman, E. L., Ahmad, S. M., \& Baker, B. S. (2002). Sex comes in from the cold: the 503 integration of sex and pattern. Trends in genetics, 18(10), 510-516.

504 Dalton, J. E., Fear, J. M., Knott, S., Baker, B. S., Mclntyre, L. M., \& Arbeitman, M. N. (2013). Male-specific $505 \quad$ Fruitless isoforms have different regulatory roles conferred by distinct zinc finger DNA binding 506 domains. BMC genomics, 14(1), 659.

507 Darriba, D., Taboada, G. L., Doallo, R., \& Posada, D. (2011). ProtTest 3: fast selection of best-fit models of $508 \quad$ protein evolution. Bioinformatics, 27(8), 1164-1165.

509 Dauwalder, B. (2011). The roles of fruitless and doublesex in the control of male courtship International 510 review of neurobiology (Vol. 99, pp. 87-105): Elsevier.

511 Dauwalder, B., Amaya-Manzanares, F., \& Mattox, W. (1996). A human homologue of the Drosophila sex determination factor transformer-2 has conserved splicing regulatory functions. Proceedings of the National Academy of Sciences, 93(17), 9004-9009.

514 Demir, E., \& Dickson, B. J. (2005). fruitless splicing specifies male courtship behavior in Drosophila. Cell, 121(5), 785-794.

Drapeau, M. D., Radovic, A., Wittkopp, P. J., \& Long, A. D. (2003). A gene necessary for normal male courtship, yellow, acts downstream of fruitless in the Drosophila melanogaster larval brain. Journal of neurobiology, 55(1), 53-72.

Flegel, T. W. (2012). Historic emergence, impact and current status of shrimp pathogens in Asia. Journal of invertebrate pathology, 110(2), 166-173.

Gailey, D. A., \& Hall, J. C. (1989). Behavior and cytogenetics of fruitless in Drosophila melanogaster: different courtship defects caused by separate, closely linked lesions. Genetics, 121(4), 773-785.

523 Galindo-Torres, P., Ventura-López, C., Llera-Herrera, R., \& Ibarra, A. M. (2019). A natural antisense transcript of the fem-1 gene was found expressed in female gonads during the characterization, 
expression profile, and cellular localization of the fem-1 gene in Pacific white shrimp Penaeus vannamei. Gene, 706, 19-31.

527

528

529

530

531

532

533

534

535

536

537

538

539

540

541

542

543

544

545

546

547

Garza-Torres, R., Campos-Ramos, R., \& Maeda-Martínez, A. M. (2009). Organogenesis and subsequent development of the genital organs in female and male Pacific white shrimp Penaeus (Litopenaeus) vannamei. Aquaculture, 296(1-2), 136-142.

Gasteiger, E., Gattiker, A., Hoogland, C., Ivanyi, I., Appel, R. D., \& Bairoch, A. (2003). ExPASy: theproteomics server for in-depth protein knowledge and analysis. Nucleic acids research, 31(13), 3784-3788.

Gempe, T., \& Beye, M. (2011). Function and evolution of sex determination mechanisms, genes and pathways in insects. Bioessays, 33(1), 52-60.

González-Castellano, I., Manfrin, C., Pallavicini, A., \& Martínez-Lage, A. (2019). De novo gonad transcriptome analysis of the common littoral shrimp Palaemon serratus: novel insights into sexrelated genes. $B M C$ genomics, $20(1), 1-15$.

Haag, E. S., \& Doty, A. V. (2005). Sex determination across evolution: connecting the dots. PLoS biology, 3(1), e21. Heinrichs, V., Ryner, L. C., \& Baker, B. S. (1998). Regulation of Sex-Specific Selection offruitless 5' Splice Sites by transformerand transformer-2. Molecular and cellular biology, 18(1), 450-458.

Inoue, K., Hoshijima, K., Higuchi, I., Sakamoto, H., \& Shimura, Y. (1992). Binding of the Drosophila transformer and transformer-2 proteins to the regulatory elements of doublesex primary transcript for sex-specific RNA processing. Proceedings of the National Academy of Sciences, 89(17), 8092-8096.

Inoue, K., Hoshijima, K., Sakamoto, H., \& Shimura, Y. (1990). Binding of the Drosophila sex-lethal gene product to the alternative splice site of transformer primary transcript. Nature, 344(6265), 461. 
548 Kato, Y., Kobayashi, K., Oda, S., Tatarazako, N., Watanabe, H., \& Iguchi, T. (2010). Sequence divergence

549 and expression of a transformer gene in the branchiopod crustacean, Daphnia magna.

$550 \quad$ Genomics, 95(3), 160-165.

551 Kato, Y., Kobayashi, K., Watanabe, H., \& Iguchi, T. (2011). Environmental sex determination in the

552 branchiopod crustacean Daphnia magna: deep conservation of a Doublesex gene in the sex-

553 determining pathway. PLoS genetics, 7(3), e1001345.

554 Katoh, K., Rozewicki, J., \& Yamada, K. D. (2019). MAFFT online service: multiple sequence alignment,

555 interactive sequence choice and visualization. Briefings in bioinformatics, 20(4), 1160-1166.

556 Letunic, I., Khedkar, S., \& Bork, P. (2021). SMART: recent updates, new developments and status in 2020.

$557 \quad$ Nucleic acids research, 49(D1), D458-D460.

558 Leelatanawit, R., Klanchui, A., Uawisetwathana, U., \& Karoonuthaisiri, N. (2012). Validation of reference

559 genes for real-time PCR of reproductive system in the black tiger shrimp. PLoS One, 7(12),

560 e52677. Leelatanawit, R., Yocawibun, P., Klinbunga, S., Roytrakul, S., Aoki, T., Hirono, I.,

$561 \quad$ Menasveta, P. (2009). Identification, characterization and expression of sex-related genes in

562 testes of the giant tiger shrimp Penaeus monodon. Comparative Biochemistry and Physiology

563 Part A: Molecular \& Integrative Physiology, Volume 152( Issue 1), 66-76.

564 Li, P., Liu, Y., Luo, D., Song, C., \& Cui, Z. (2017). Two spliced isoforms of the sex-determination gene

565 fruitless in the Chinese mitten crab Eriocheir sinensis. Comparative Biochemistry and Physiology

$566 \quad$ Part B: Biochemistry and Molecular Biology, 208, 75-83.

567 Li, S., Li, F., Wen, R., \& Xiang, J. (2012). Identification and characterization of the sex-determiner 568 transformer-2 homologue in Chinese shrimp, Fenneropenaeus chinensis. Sexual Development,

569 $6(5), 267-278$. 
570 Li, S., Li, F., Yu, K., \& Xiang, J. (2018). Identification and characterization of a doublesex gene which

571 regulates the expression of insulin-like androgenic gland hormone in Fenneropenaeus chinensis.

$572 \quad$ Gene.

573 Li, Y., Byrne, K., Miggiano, E., Whan, V., Moore, S., Keys, S., Lehnert, S. (2003). Genetic mapping of the 574 kuruma prawn Penaeus japonicus using AFLP markers. Aquaculture, 219(1-4), 143-156.

575 Liu, Y., Hui, M., Cui, Z., Luo, D., Song, C., Li, Y., \& Liu, L. (2015). Comparative transcriptome analysis 576 reveals sex-biased gene expression in juvenile Chinese mitten crab Eriocheir sinensis. PLoS One, $577 \quad$ 10(7), e0133068.

578 Livak, K. J., \& Schmittgen, T. D. (2001). Analysis of relative gene expression data using real-time 579 quantitative PCR and the 2- $\Delta \Delta C T$ method. methods, 25(4), 402-408.

López-Cuadros, I., García-Gasca, A., Gomez-Anduro, G., Escobedo-Fregoso, C., Llera-Herrera, R. A., \& Ibarra, A. M. (2018). Isolation of the sex-determining gene Sex-lethal (SxI) in Penaeus (Litopenaeus) vannamei (Boone, 1931) and characterization of its embryogenic, gametogenic, and tissue-specific expression. Gene, 668, 33-47.

Mandal, A., Rao, D., Karuppaiah, D., Gopalakrishnan, A., Pozhoth, J., Samraj, Y. C. T., \& Doyle, R. W. (2012). Population genetic structure of Penaeus monodon, in relation to monsoon current patterns in Southwest, East and Andaman coastal waters of India. Gene, 491(2), 149-157. characterization of the complete cDNA sequence encoding a putative insulin-like peptide from the androgenic gland of Penaeus monodon. Aquaculture, 318(3-4), 364-370. 
593 McMillan, N. (2018). Identification and expression analysis of sex-related Transformer-2 gene in giant $594 \quad$ river prawn, Macrobrachium rosenbergii.

595

596

597

598

599

600

601

602

603

604

605

606

607

608

609

610

611

612

613

614

615

616

Motulsky, H. J. (2007). Prism 5 statistics guide. GraphPad Software Inc.: San Diego, CA, USA.

Nagoshi, R. N., McKeown, M., Burtis, K. C., Belote, J. M., \& Baker, B. S. (1988). The control of alternative splicing at genes regulating sexual differentiation in D. melanogaster. Cell, 53(2), 229-236.

Nakamura, K., Matsuzaki, N., \& Yonekura, K. (1992). Organogenesis of genital organs and androgenic gland in the kuruma prawn [Penaeus japonicus]. Bulletin of the Japanese Society of Scientific Fisheries (Japan).

Niu, B.-L., Meng, Z.-Q., Tao, Y.-Z., Lu, S.-L., Weng, H.-B., He, L.-H., \& Shen, W.-F. (2005). Cloning and alternative splicing analysis of Bombyx mori transformer-2 gene using silkworm EST database. Acta biochimica et biophysica Sinica, 37(11), 728-736.

Nogueira, C. d. S., Perroca, J. F., Piantkoski, E. L., Costa, R. C. d., Taddei, F. G., \& Fransozo, A. (2019). Relative growth and population dynamics of Macrobrachium iheringi (Decapoda, Palaemonidae). Papéis Avulsos de Zoologia, 59.

Nöthiger, R., \& Steinmann-Zwicky, M. (1985). Sex determination in Drosophila. Trends in Genetics, 1, 209-215.

Penalva, L. O., \& Sánchez, L. (2003). RNA binding protein sex-lethal (SxI) and control of Drosophila sex determination and dosage compensation. Microbiology and molecular biology reviews, 67(3), 343-359.

Pomiankowski, A., Nöthiger, R., \& Wilkins, A. (2004). The evolution of the Drosophila sex-determination pathway. Genetics, 166(4), 1761-1773.

Robinson, N. A., Gopikrishna, G., Baranski, M., Katneni, V. K., Shekhar, M. S., Shanmugakarthik, J., Gitterle, T. (2014). QTL for white spot syndrome virus resistance and the sex-determining locus in the Indian black tiger shrimp (Penaeus monodon). BMC genomics, 15(1), 1-21.

Peer) reviewing PDF | (2021:05:60965:4:1:NEW 24 Jan 2022) 
617 Ryner, L. C., Goodwin, S. F., Castrillon, D. H., Anand, A., Villella, A., Baker, B. S., Wasserman, S. A. (1996).

618 Control of male sexual behavior and sexual orientation in Drosophila by the fruitless gene. Cell, 619 87(6), 1079-1089.

620 Salvemini, M., D'Amato, R., Petrella, V., Aceto, S., Nimmo, D., Neira, M., Saccone, G. (2013). The 621 orthologue of the fruitfly sex behaviour gene fruitless in the mosquito Aedes aegypti: evolution of genomic organisation and alternative splicing. PloS one, 8(2), e48554.

Salvemini, M., Polito, C., \& Saccone, G. (2010). fruitless alternative splicing and sex behaviour in insects: an ancient and unforgettable love story? Journal of genetics, 89(3), 287-299.

Sánchez, L. (2004). Sex-determining mechanisms in insects. International journal of developmental biology, 52(7), 837-856.

Staelens, J., Rombaut, D., Vercauteren, I., Argue, B., Benzie, J., \& Vuylsteke, M. (2008). High-density linkage maps and sex-linked markers for the black tiger shrimp (Penaeus monodon). Genetics,

629 179(2), 917-925.

Stamatakis, A. (2014). RAxML version 8: a tool for phylogenetic analysis and post-analysis of large phylogenies. Bioinformatics, 30(9), 1312-1313.

Wang, M., Xie, X., Zheng, L., Zheng, H., Yu, G., Jin, Z., \& Zhu, D. (2020). Molecular characterization of transformer-2 gene in the mud crab Scylla paramamosain and its putative role in sexual development. Aquaculture Research, 51(8), 3154-3165. analysis, and in situ hybridization of a Transformer-2 gene in the oriental freshwater prawn, Macrobrachium nipponense (de Haan, 1849). 3 Biotech, 9(6), 1-11. 
638 Watanabe, T. (2019). Evolution of the neural sex-determination system in insects: does fruitless

639

640

641

642

643

644

645

646

647

648

649

650

651

652

653

654

655

656

\section{Table legends:}

658

659 807-827. homologue regulate neural sexual dimorphism in basal insects? Insect molecular biology, 28(6),

Yamamoto, D. (2008). Brain sex differences and function of the fruitless gene in Drosophila. Journal of neurogenetics, 22(3), 309-332.

Zhang, L., Yang, C., Zhang, Y., Li, L., Zhang, X., Zhang, Q., \& Xiang, J. (2007). A genetic linkage map of Pacific white shrimp (Litopenaeus vannamei): sex-linked microsatellite markers and high recombination rates. Genetica, 131(1), 37-49.

Zhang, Y., Fu, H., Qiao, H., Jin, S., Jiang, S., Xiong, Y., Zhang, X. (2013). Molecular cloning and expression analysis of transformer-2 gene during development in Macrobrachium nipponense (de Haan 1849). Journal of the World Aquaculture Society, 44(3), 338-349.

Zhang, Y., Qiao, H., Zhang, W., Sun, S., Jiang, S., Gong, Y., Fu, H. (2013). Molecular cloning and expression analysis of two sex-lethal homolog genes during development in the oriental river prawn, Macrobrachium nipponense. Genetics and Molecular Research, 12(4), 4698-4711.

Zollman, S., Godt, D., Prive, G. G., Couderc, J.-L., \& Laski, F. A. (1994). The BTB domain, found primarily in zinc finger proteins, defines an evolutionarily conserved family that includes several developmentally regulated genes in Drosophila. Proceedings of the National Academy of Sciences, 91(22), 10717-10721.

Table 1. Accession numbers of Tra 2 homologous amino acid sequences used for multiple sequence alignment and phylogenic tree analyses. 
660 Table 2. Accession numbers of Fru homologous amino acid sequences used for multiple sequence

661 alignment and phylogenic tree analyses.

662 Table 3. Specific primers used in this study.

663

664 Figure legends:

665 Figure 1. Putative amino acid sequences with predicted domains of PmOvtra 2. (A) Schematic 666 presentation of amino acid sequences with predicted domains of PmOvtra 2 showing RRM 667 domain and two RS regions which are conserved among Tra 2 homologs. (B) Deduced amino 668 acid sequences with predicted domains of PmOvtra 2. The conserved sequences in the part of 669 RRM domain were located at 103-176 aa in PmOvtra 2. (C) Multiple alignments of the RRM 670 domain and two RS regions of PmOvtra 2 with Tra 2 homologs from other species showing 671 highly conserved residues in all Tra 2 homologs. Conserved residues in all homologs were 672 marked with black shadow. Partly conserved residues were marked with gray shadow.

673 Figure 2. Putative amino acid sequences with predicted domains of Pmfru-1 and Pmfru-2. (A)

674 Schematic presentation of amino acid sequences with predicted domains of Pmfru-1 and Pmfru-2 675 showing BTB domain and zinc finger domain which are conserved among Fru homologs. The 676 BTB domain and zinc finger domain of Pmfru-1 are located at 31-126 aa and 339-389 aa, 677 respectively, while that of Pmfru-2 are at 31-126 aa and 373-395 / 401-424 aa. (B) and (C) 678 Multiple alignments of BTB domain and zinc finger domain of Pmfru-1, Pmfru-2, and Fru 679 homologs from other species. Conserved residues in all homologs were marked with black 680 shadow. Partly conserved residues were marked with gray shadow.

681 Figure 3. Phylogenetic placements of PmOvtra 2 and PmTra 2 on a maximum likelihood tree of 682 Tra2 homologous sequences in arthropods and crustaceans. Two separated sister clades 
683 containing PmOvtra 2 and PmTra 2 are clearly indicated by two dashed-line rectangles.

684 Previously functional characterized sequences are underlined and with gene names. Bootstrap 685 values (expressed as percentages of 1000 replications) are near branching points, and Drosophila 686 melanogaster ortholog was used as an outgroup.

687 Figure 4. Phylogenetic placements of Pmfru-1 and Pmfru-2 on a maximum likelihood tree of 688 Fru homologous sequences in arthropods and crustaceans. Previously functional characterized 689 sequences are underlined and with gene names. Bootstrap values (expressed as percentages of 6901000 replications) are near branching points, and Chelicerata orthologs (Araneus ventricosus and 691 Nymphon striatum) were used as an outgroup.

692 Figure 5. A schematic diagram shows alternative splicing of Pmfru-1 and Pmfru-2 from the 693 Penaeus monodon genomic region of seven exons (colored boxes). Exons 1 to 7 are of 87, 95, $694594,243,90,761$, and 197 bp in length, respectively. Constitutive splicing and alternative 695 splicing events are depicted by connecting solid and dashed lines, respectively. Mature Pmfru-1 696 and Pmfru-2 mRNAs share constitutive splicing exons 1-5, and alternative splicing events 697 include mutually exclusive exon 6 for Pmfru-2 and exon 7 for Pmfru-1. The start (ATG) and 698 stop (TGA) codons are represented by red vertical bars on exon 2 and exon $7 \&$ exon 6 , 699 respectively.

700 Figure 6. Temporal expression of PmOvtra 2, Pmfru-1, and Pmfru-2. (A) Relative expression of 701 PmOvtra 2. (B) Relative expression of Pmfru-1. (C) Relative expression of Pmfru-2. The relative 702 expression levels of these genes were analyzed by qPCR in different developmental stages of $P$. 703 monodon including nauplius, protozoea, mysis and postlarvae (PL1, 5, 10, and 15). The PmOvtra 2, Pmfru-1 and Pmfru-2 mRNA levels were normalized to the $16 s$ rRA mRNA level. Data represent the mean \pm standard deviation (S.D.). Statistical significance was calculated by 
706 Tukey's multiple comparison tests and one-way ANOVA. The significant difference was

707 indicated by lettered bars $(p<0.05)$.

708 Figure 7. Tissue distribution of PmOvtra 2, Pmfru-1, and Pmfru-2 in P. monodon. Expressions

709 of PmOvtra 2, Pmfru-1, Pmfru-2 were investigated in eyestalk (ES), central nervous system

710 (CNS), gill, hepatopancreas (HP), heart (Hea), gastrointestinal tract (GI), testis (Tes), and ovary

711 (Ova) by RT-PCR. M and N represented molecular weight markers and negative control,

712 respectively. PmOvtra 2, Pmfru-1 and Pmfru-2 transcripts showed the specific band at $449 \mathrm{bp}$,

$713262 \mathrm{bp}$, and $345 \mathrm{bp}$, respectively. The 16s rRNA, showing the band at $152 \mathrm{bp}$, was utilized as an

714 internal control.

715 Figure 8. Relative expressions of PmOvtra 2, Pmfru-1, and Pmfru-2 in testes and ovaries

716 revealed by qPCR. (A) Relative expression of PmOvtra 2. (B) Relative expression of Pmfru-1.

717 (C) Relative expression of Pmfru-2. The mRNA expression level of PmOvtra 2, Pmfru-1, and

718 Pmfru-2 were normalized to the 16s rRNA transcript level. The result showed a greatly high

719 expression level of PmOvtra 2, Pmfru-1, and Pmfru-2 in the ovary when compared with the

720 testis. Data represented the mean \pm standard deviation (S.D.). Statistical significance was

721 calculated by unpaired t-test. The significant difference was indicated by two asterisks $(* *)(p<$

722 0.01).

723

724 Supplemental data:

725 Supplement 1. Nucleotide (above) and deduced amino acid (below) sequences of PmOvtra 2.

726 The nucleotide sequences encoding the start codon are underlined, and the stop codon are

727 underlined with an asterisk (*) below. The RS-1 and RS-2 regions are blue and green underlined,

728 respectively. The RRM domain is marked with gray shadow located at 101-180 aa.

Peer] reviewing PDF | (2021:05:60965:4:1:NEW 24 Jan 2022) 
729 Supplement 2. Nucleotide (above) and deduced amino acid (below) sequences of Pmfru-1 and

730 Pmfru-2. The nucleotide sequences encoding the start codon are underlined and the stop codon

731 are underlined with an asterisk $(*)$. The predicted BTB and ZF domains were marked with gray

732 shadow located at 31-126 aa, 339-389 aa in Pmfru-1, and at 31-126 aa and (373-395, 401-424)

733 aa in Pmfru-2.

734 Supplement 3. Comparison of threshold cycles (CT) values of three reference genes, 16s rRNA, 735 ef $1-\alpha$, and $\beta$-actin, in testes and ovaries.

736 Supplement 4. Comparison of threshold cycles (CT) values of three reference genes, 16s rRNA,

737 ef1- $\alpha$, and $\beta$-actin, in various stages of larvae and post-larvae.

738 Nucleotide sequence of PmOvTra 2 (Word file)

739 Nucleotide sequence of PmFru-1 gene (Word file)

740 Nucleotide sequence of PmFru-2 gene (Word file)

741 Raw data of Figure 6 (Excel file)

742 Raw data of Figure 8 (Excel file)

743 Uncropped gel picture of Figure 7 (Zip file)

744 Raw data of supplement 3 (Excel file)

745 Raw data of supplement 4 (Excel file) 


\section{Table $\mathbf{1}$ (on next page)}

Accession numbers of Tra 2 homologous amino acid sequences used for multiple sequence alignment and phylogenic tree analyses. 
1 Table 1. Accession numbers of Tra 2 homologous amino acid sequences used for multiple sequence alignment and phylogenic tree analyses.

\begin{tabular}{|c|c|c|c|c|c|c|}
\hline \multirow[t]{2}{*}{ Species } & \multirow[t]{2}{*}{ Subphylum/Class } & \multirow[t]{2}{*}{ Order } & \multirow[t]{2}{*}{ Family } & \multirow[t]{2}{*}{$\begin{array}{l}\text { Accession } \\
\text { number }\end{array}$} & \multicolumn{2}{|c|}{ Gene name } \\
\hline & & & & & $\begin{array}{l}\text { with functional study } \\
\text { (Reference) }\end{array}$ & $\begin{array}{l}\text { putatively annotated without } \\
\text { functional study }\end{array}$ \\
\hline Penaeus monodon & Crustacea/Malacostraca & Decapoda & Penaeidae & MT543028 & PmOvtra 2 (this study) & \\
\hline Penaeus monodon & Crustacea/Malacostraca & Decapoda & Penaeidae & ACD13597 & $\begin{array}{l}\text { Pmtra } 2 \text { (Rungnapa } \\
\text { Leelatanawit, 2009) }\end{array}$ & \\
\hline Penaeus chinensis & Crustacea/Malacostraca & Decapoda & Penaeidae & AFU60541.1 & Pctra 2b (S. Li et al., 2012) & \\
\hline Penaeus vannamei & Crustacea/Malacostraca & Decapoda & Penaeidae & XP_027230515.1 & & $\begin{array}{l}\text { Transformer-2 protein homolog } \\
\text { alpha-like }\end{array}$ \\
\hline Penaeus vannamei & Crustacea/Malacostraca & Decapoda & Penaeidae & XP_027226065.1 & & $\begin{array}{l}\text { Transformer-2 protein homolog } \\
\text { alpha-like isoform X2 }\end{array}$ \\
\hline Scylla paramamosain & Crustacea/Malacostraca & Decapoda & Portunidae & QNS26380.1 & Sptra 2 (M. Wang et al., 2020) & \\
\hline Cherax quadricarinatus & Crustacea/Malacostraca & Decapoda & Parastacidae & QIH97833.1 & Cqtra 2b (Cai et al., 2020) & \\
\hline Eriocheir sinensis & Crustacea/Malacostraca & Decapoda & Varunidae & APJ36535.1 & Estra 2c (Luo et al., 2017) & \\
\hline Homarus americanus & Crustacea/Malacostraca & Decapoda & Nephropidae & KAG7172586.1 & & Transformer-2 protein beta-like \\
\hline Macrobrachium nipponense & Crustacea/Malacostraca & Decapoda & Palaemonidae & QBS13802.1 & $\begin{array}{l}\text { Mntra 2a } \\
\text { (Y. Wang et al., 2019) }\end{array}$ & \\
\hline Macrobrachium rosenbergii & Crustacea/Malacostraca & Decapoda & Palaemonidae & QBY91826.1 & Mrtra 2a (McMillan, 2018) & \\
\hline Drosophila melanogaster & Insecta & Diptera & Drosophilidae & NP_476764.1 & Dmtra 2 (Amrein et al., 1988) & \\
\hline
\end{tabular}




\section{Table 2 (on next page)}

Accession numbers of Fru homologous amino acid sequences used for multiple sequence alignment and phylogenic tree analyses. 
1 Table 2. Accession numbers of Fru homologous amino acid sequences used for multiple sequence alignment and phylogenic tree analyses.

\begin{tabular}{|c|c|c|c|c|c|c|}
\hline \multirow[t]{2}{*}{ Species } & \multirow[t]{2}{*}{ Subphylum/Class } & \multirow[t]{2}{*}{ Order } & \multirow[t]{2}{*}{ Family } & \multirow[t]{2}{*}{ Accession number } & \multicolumn{2}{|c|}{ Gene name } \\
\hline & & & & & $\begin{array}{l}\text { with functional } \\
\text { study (Reference) }\end{array}$ & $\begin{array}{l}\text { putatively annotated } \\
\text { without functional study }\end{array}$ \\
\hline Penaeus monodon & Crustacea/Malacostraca & Decapoda & Penaeidae & MT497519 & Pmfru-1 (this study) & \\
\hline Penaeus monodon & Crustacea/Malacostraca & Decapoda & Penaeidae & MT503286 & Pmfru-2 (this study) & \\
\hline Penaeus vannamei & Crustacea/Malacostraca & Decapoda & Penaeidae & XP_027234425.1 & & $\begin{array}{l}\text { Longitudinals lacking protein, } \\
\text { isoforms } \mathrm{H} / \mathrm{M} / \mathrm{V} \text {-like isoform } \mathrm{X} 1\end{array}$ \\
\hline Eriocheir sinensis & Crustacea/Malacostraca & Decapoda & Varunidae & ART29432.1 & $\begin{array}{l}\text { Esfru-2 } \\
\text { (P. Li et al., 2017) }\end{array}$ & \\
\hline Eriocheir sinensis & Crustacea/Malacostraca & Decapoda & Varunidae & ART29431.1 & $\begin{array}{l}\text { Esfru-1 } \\
\text { (P. Li et al., 2017) }\end{array}$ & \\
\hline Hyalella azteca & Crustacea/Malacostraca & Amphipoda & Hyalellidae & XP_018020859.1 & & $\begin{array}{l}\text { Sex determination protein } \\
\text { fruitless-like isoform X1 }\end{array}$ \\
\hline Daphnia magna & Crustacea/Branchiopoda & Cladocera & Daphniidae & XP_032789566.1 & & $\begin{array}{l}\text { Longitudinals lacking protein, } \\
\text { isoforms } \mathrm{F} / \mathrm{I} / \mathrm{K} / \mathrm{T} \text {-like }\end{array}$ \\
\hline Daphnia pulex & Crustacea/Branchiopoda & Cladocera & Daphniidae & EFX71514.1 & & Hypothetical protein \\
\hline Nasonia vitripennis & Insecta & Hymenoptera & Pteromalidae & NP_001157594.1 & $\begin{array}{l}\text { Nvfru } \\
\text { (Bertossa et al., 2009) }\end{array}$ & \\
\hline Aedes aegypti & Insecta & Diptera & Culicidae & AGC11799.1 & $\begin{array}{l}\text { Aafru } \\
\text { (Salvemini et al., 2013) }\end{array}$ & \\
\hline Drosophila melanogaster & Insecta & Diptera & Drosophilidae & NP_732344.1 & $\begin{array}{l}\text { Dmfru } \\
\text { (Ryner et al., 1996) }\end{array}$ & \\
\hline Drosophila melanogaster & Insecta & Diptera & Drosophilidae & AAB96677.1 & $\begin{array}{l}\text { Dmfru } \\
\text { (Ryner et al., 1996) }\end{array}$ & \\
\hline Araneus ventricosus & Chelicerata & Araneae & Araneidae & GBM78970.1 & & Protein bric-a-brac 2 \\
\hline Nymphon striatum & Chelicerata & Pantopoda & Nymphonidae & KAG1658585.1 & & Protein bric-a-brac 2 \\
\hline
\end{tabular}


Table 3 (on next page)

Specific primers used in this study. 
1

2 Table 3. Specific primers used in this study.

3

\begin{tabular}{lllc}
\hline \multicolumn{1}{c}{ Name } & Primers sequence $\left(\mathbf{5}^{\prime} \rightarrow \mathbf{3}^{\prime}\right)$ & Description & PCR product size \\
\hline PmOvtra 2 F & AGTTCGTGAAAGGTCGAGGG & RT-PCR, qPCR & $449 \mathrm{bp}$ \\
PmOvtra 2 R & CAGTACACTGCTCCTTGGCT & RT-PCR, qPCR & \\
Pmfru-1 F & GGAGGCAAGCATCAGTTTCG & RT-PCR, qPCR & 262 bp \\
Pmfru-1 R & AGATCGTTTGGGTCCCCTCA & RT-PCR, qPCR & \\
Pmfru-2 F & AGGCAGCTGACAACAATGCT & RT-PCR, qPCR & \multirow{2}{*}{$345 \mathrm{bp}$} \\
Pmfru-2 R & TTTTGGGTTATGAGGTGTGCCT & RT-PCR, qPCR & \\
$16 \mathrm{~s}$ rRNA F & TGACCGTGCRAAGGTAGCATA & RT-PCR, qPCR & $152 \mathrm{bp}$ \\
$16 \mathrm{~s}$ rRnA R & TTTATAGGGTCTTATCGTCCC & RT-PCR, qPCR & \\
\hline
\end{tabular}

4

5 


\section{Figure 1}

Putative amino acid sequences with predicted domains of PmOvtra 2.

(A) Schematic presentation of amino acid sequences with predicted domains of PmOvtra 2 showing RRM domain and two RS regions which are conserved among Tra 2 homologs. (B) Deduced amino acid sequences with predicted domains of PmOvtra 2. The conserved sequences in the part of RRM domain were located at 103-176 aa in PmOvtra 2. (C) Multiple alignments of the RRM domain and two RS regions of PmOvtra 2 with Tra 2 homologs from other species showing highly conserved residues in all Tra 2 homologs. Conserved residues in all homologs were marked with black shadow. Partly conserved residues were marked with gray shadow. 
A

B

Penaeus monodon (PmOvtra2) Penaeus monodon (Pmtra2) Macrobrachium nipponense Macrobrachium rosenbergi i Penaeus chinensis Penaeus vannamei

Penaeus monodon (PmOvtra2) Penaeus monodon (Pmtra2) Macrobrachium nipponense Macrobrachium rosenbergii Penaeus chinensis

Penaeus vannamei

Penaeus monodon (PmOvtra2) Penaeus monodon (Pmtra2) Macrobrachium nipponense Macrobrachium rosenbergii Penaeus chinensis

Penaeus vannamei

Penaeus monodon (Pmovtra2) Penaeus monodon (Pmtra2) Macrobrachium nipponense Macrobrachium rosenbergii Penaeus chinensis Penaeus vannamei

Penaeus monodon (PmOvtra2) Penaeus monodon (Pmtra2) Macrobrachium nipponense Macrobrachium rosenbergii Penaeus chinensis Penaeus vannamei

Penaeus monodon (PmOvtra2) Penaeus monodon (Pmtra2) Macrobrachium nipponense Macrobrachium rosenbergii Penaeus chinensis Penaeus vannamei

Penaeus monodon (PmOvtra2) Penaeus monodon (Pmtra2) Macrobrachium nipponense Macrobrachium rosenbergii Penaeus chinensis Penaeus vannamei

Penaeus monodon (PmOvtra2) Penaeus monodon (Pmtra2 Macrobrachium nipponense Macrobrachium rosenbergif Penaeus chinensis Penaeus vannamei
RS1 RS2

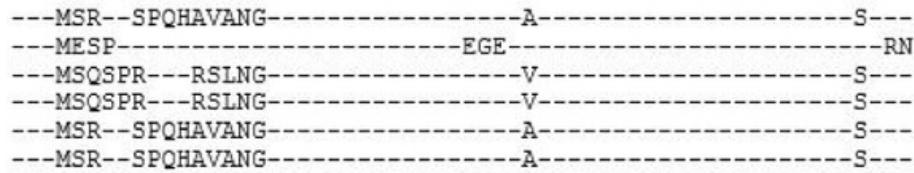

---------PVR--ERSRDPSFSRSRSRSRDRRETYKHSSRSSGSPRYRED-RYREDK SLTP---------------RSRSRSRSRLESPAASPAH--RRTATSQSRSPQ-PRRRS ---------PSRDRSRDRDPSFSRSRSRSSDRRDSYKYSSRRSTSPRYREE-RYRDDK ---------PSRDGSRDRDPSFSRSRSRSSDRRDSYKYSSRRSTSPRYREE-RYRDDK --------PVR--ERSRDPSFSRSRSRSRDRRETYKHSSRSSGSPRYRED-RYREEK ---------PVR--ERSRDPSFSRSRSRSRDRRETYKHSSRSSGSPRYREE-RYREDK

YSS----SRRR----DSRSPSYS--FSRS----RSRTPRR-HRSRSGS----PRNGH--DGS-------------SRRSRRSRS

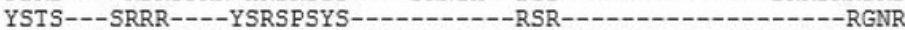
YSTS---SRRR-----YSRSPSYS------------RSR------------------RGNR YSS----SRRR----DSRSPSYS----------RRR----------------YSS-----SRRR----DSRSPSYS-----------RRR---------------------RSNRSPMSNRRRHH-__ron 1 region - GSREDPSPSNCLGIFGLSI

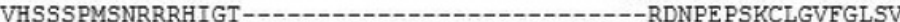
SRTRSPMSTRRRHH--------------------GSREDPSPSTCLGVFGLSI SRTRS PMSTRRRHH-------------------GSREDPSPSTCLGVFGLSI RTNRS PVSNRRRHH---------_-_----GSREDPSPSNCLGIFGLSI RSNRSPMSNRRRHH------------------------GSREDPSPSNCLGIFGLSI $* * * *$ * $\quad: *: * *:$.

RS 1 region HTTERQLYTIFDKFGPLEKVQVVLDSKTGKSRGFAFVYFESLKDASEAKNECSGMEIDGR YTSERQLHHLFGKYGPLAKVOVVLDAKTGRSRGFAFIYFEHMDDATEAKEOCTGMEIDGR YTSERQLHHLFGKYGPLSKVQVVLDAKTGRSRGFAFIYFEHMDDATEAKEOCTGME IDGR YTTERQLHHLFGKYGHINEVQVVLDAKTGRSRGFAFIYFDHVDDATEAKEOCTGMEIDGR YTTERQLHHLFGKYGHINEVQVVLDAKTGRSRGFAFIYFDHVDDATEAKDQCTGMEIDGR

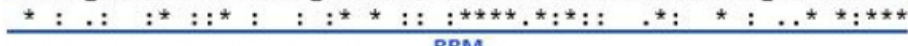
RRM

RIRVDYSITERAHTPTPGIYMGRPTY--SNNGRR------------------------RIRVDYSITKRPHTPTPGIYMGRPISRGGYDRGYG---RGGHRGDRYRSPSPRYRPRSSG

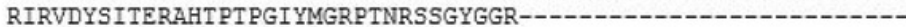

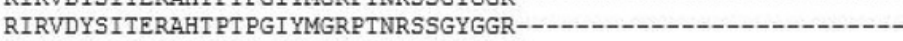

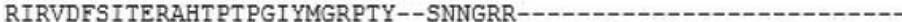
RIRVDYSITERAHTPTPGIYMGRPTY--SNNGRR--$: * * * *: * * *: * * * * * * *: *: *$ :

\begin{tabular}{|c|}
\hline RS 2 region \\
\hline 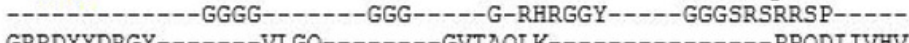 \\
\hline 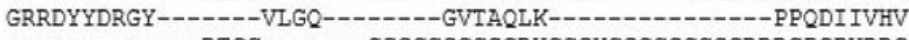 \\
\hline $\begin{array}{lll}--1-1 & -1-1\end{array}$ \\
\hline 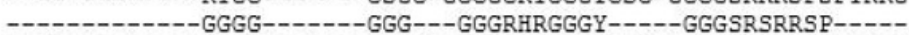 \\
\hline ---------GGGG-------GGG-----G-RHRGGY-----GGGSRSRRSP----- \\
\hline ------PRRSYRSRSRSYSPRRYSRY-RS 2 region \\
\hline 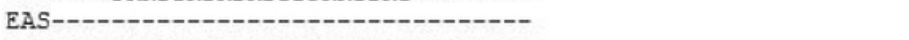 \\
\hline RS-----GRNSYRSRSRSYSPRRA----------- \\
\hline RS-----GRNSYRSRSRSYSPRRYSRY-------- \\
\hline -------PRRSYRSRSRSYSPRK------------ \\
\hline -------PRRSYRSRSRSYSPRRYSRY-------- \\
\hline
\end{tabular}

RS 2 region

\section{C}

Penaeus monodon (PmOvtra2) Penaeus monodon (Pmtra2) Penaeus chinensis Penaeus vannamei Macrobrachium nipponense Macrobrachium rosenbergii

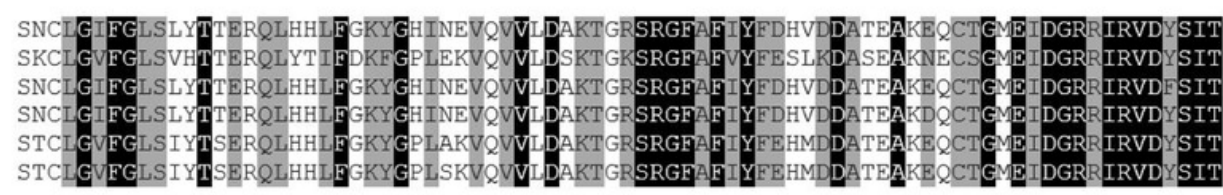


Figure 2

Putative amino acid sequences with predicted domains of Pmfru-1 and Pmfru-2.

(A) Schematic presentation of amino acid sequences with predicted domains of Pmfru-1 and Pmfru-2 showing BTB domain andzinc finger domain which are conserved among Fru homologs. The BTB domain andzinc finger domain of Pmfru-1 are located at 31-126 aa and 339-389 aa, respectively, while that of Pmfru-2 are at 31-126 aa and 373-395 / 401-424 aa. (B) and (C) Multiple alignments of BTB domain and zinc finger domain of Pmfru-1, Pmfru-2, and Fru homologs from other species. Conserved residues in all homologs were marked with black shadow. Partly conserved residues were marked with gray shadow.

A

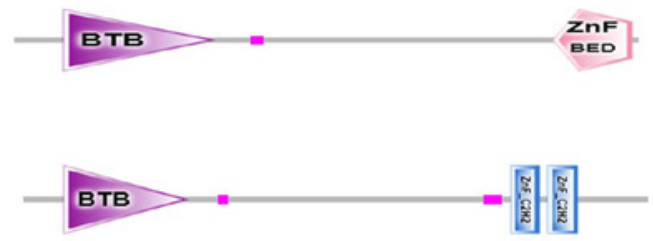

B

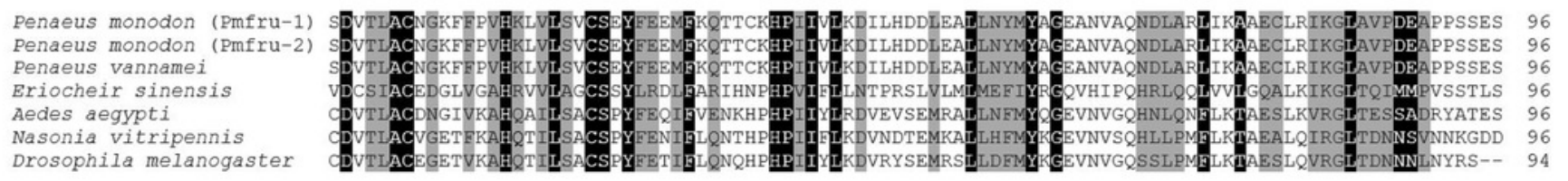

C

Penaeus monodon (Pmfru-1) Penaeus monodon (Pmfru-2) Nasonia vitripennis Aedes aegypti Drosophila melanogaster

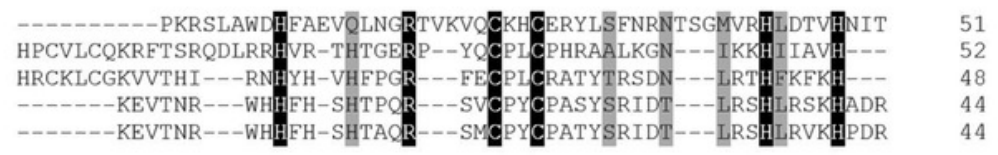




\section{Figure 3}

Phylogenetic placements of PmOvtra 2 and PmTra 2 on a maximum likelihood tree of Tra2 homologous sequences in arthropods and crustaceans.

Two separated sister clades containing PmOvtra 2 and PmTra 2 are clearly indicated by two dashed-line rectangles. Previously functional characterized sequences are underlined and with gene names. Bootstrap values (expressed as percentages of 1000 replications) are near branching points, and human orthologs (Tra2A and Tra2B) were used as an outgroup.

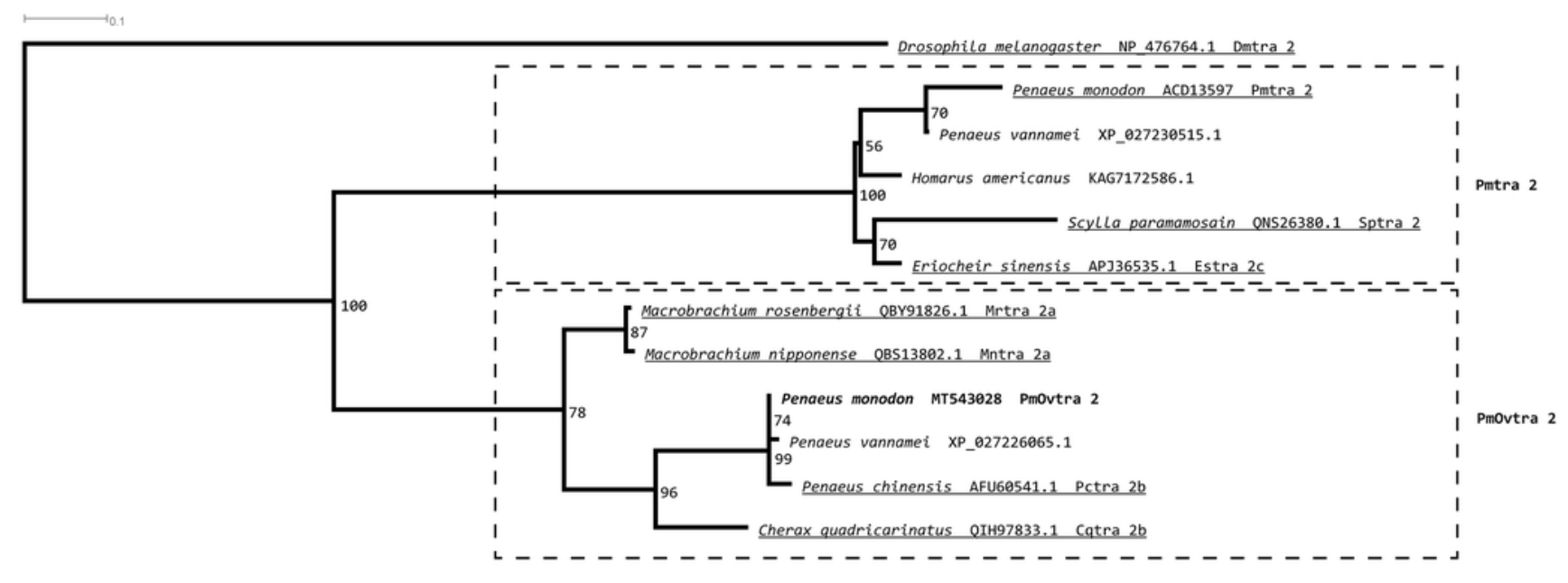




\section{Figure 4}

Phylogenetic placements of Pmfru-1 and Pmfru-2 on a maximum likelihood tree of Fru homologous sequences in arthropods and crustaceans.

Previously functional characterized sequences are underlined and with gene names.

Bootstrap values (expressed as percentages of 1000 replications) are near branching points, and Chelicerata orthologs (Araneus ventricosus and Nymphon striatum) were used as an outgroup.

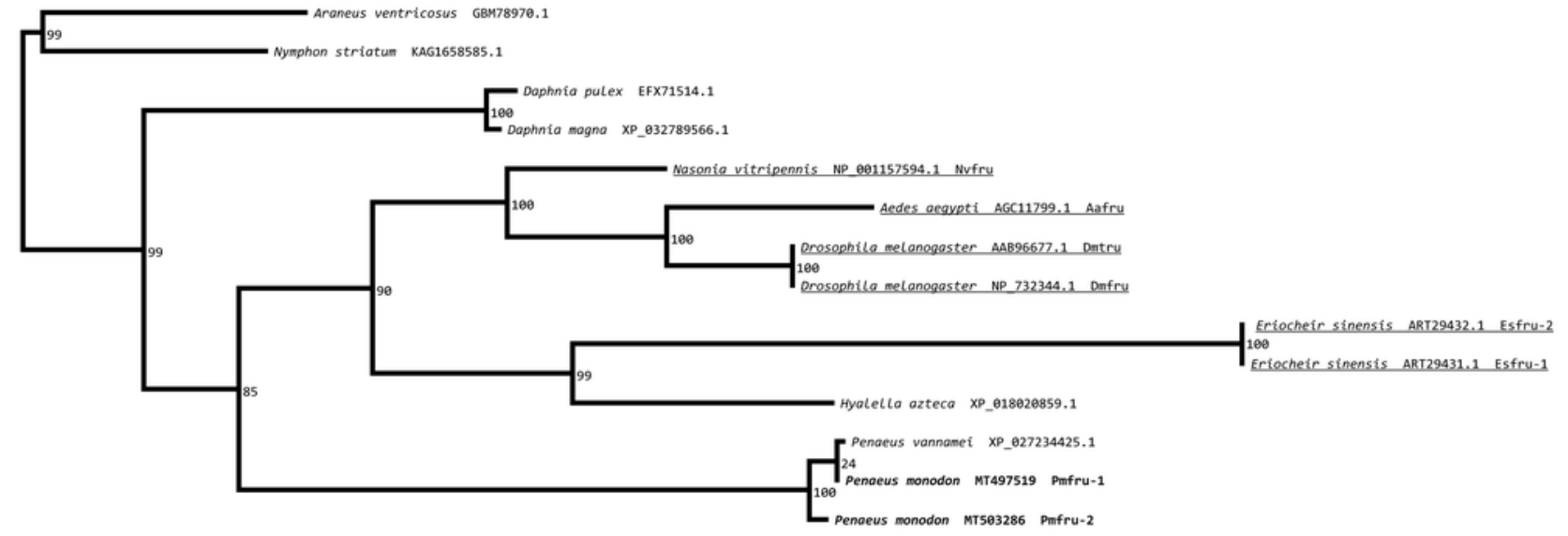




\section{Figure 5}

Schematic diagram shows alternative splicing of Pmfru-1 and Pmfru-2 from the Penaeus monodon genomic region of seven exons.

Schematic diagram shows alternative splicing of Pmfru-1 and Pmfru-2 from the Penaeus monodon genomic region of seven exons (colored boxes). Exons 1 to 7 are of 87, 95, 594, 243, 90, 761 and 197 bp in length, respectively. Constitutive splicing and alternative splicing events are depicted by connecting solid and dashed lines, respectively. Mature Pmfru-1 and Pmfru-2 mRNAs share constitutive splicing exons 1-5, and alternative splicing events include mutually exclusive exon 6 for Pmfru-2 and exon 7 for Pmfru-1. The start (ATG) and stop (TGA) codons are represented by red vertical bars on exon 2 and exon $7 \&$ exon 6 , respectively.

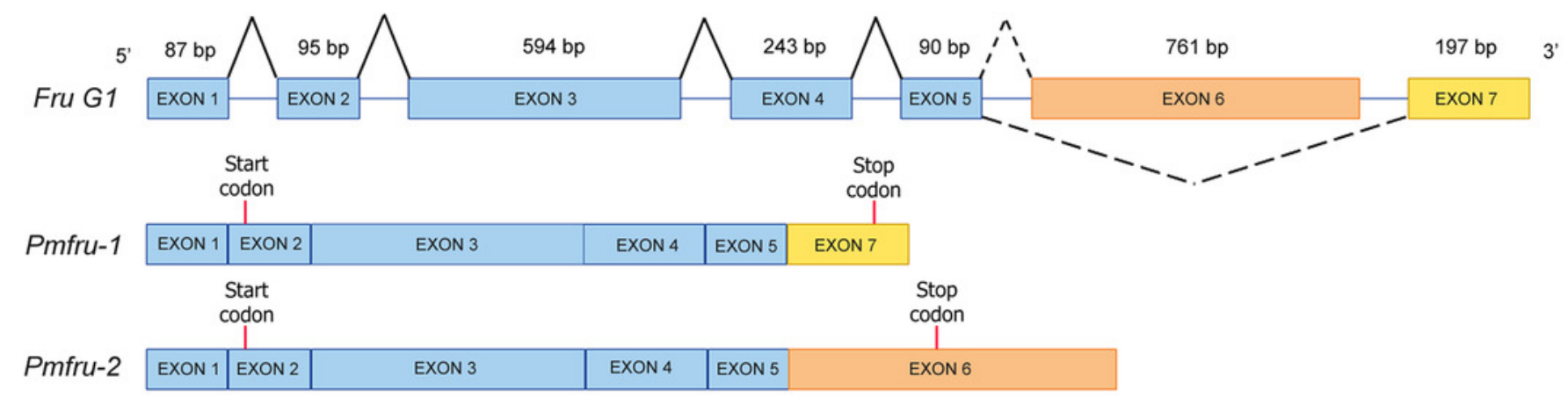




\section{Figure 6}

Temporal expression of PmOvtra 2, Pmfru-1, and Pmfru-2.

Temporal expression of PmOvtra 2, Pmfru-1, and Pmfru-2. (A) Relative expression of PmOvtra

2. (B) Relative expression of Pmfru-1. (C) Relative expression of Pmfru-2. The relative expression levels of these genes were analyzed by RT-qPCR in different developmental stages of $P$. monodon including nauplius, protozoea, mysis and postlarvae (PL1, 5, 10, and 15). The PmOvtra 2, Pmfru-1 and Pmfru-2 mRNA levels were normalized to the 16s rRNA mRNA level. Data represent the mean \pm standard deviation (S.D.). Statistical significance was calculated by tukey's multiple comparison tests and one-way ANOVA. The significant difference was indicated by lettered bars $(p<0.05)$. 
A

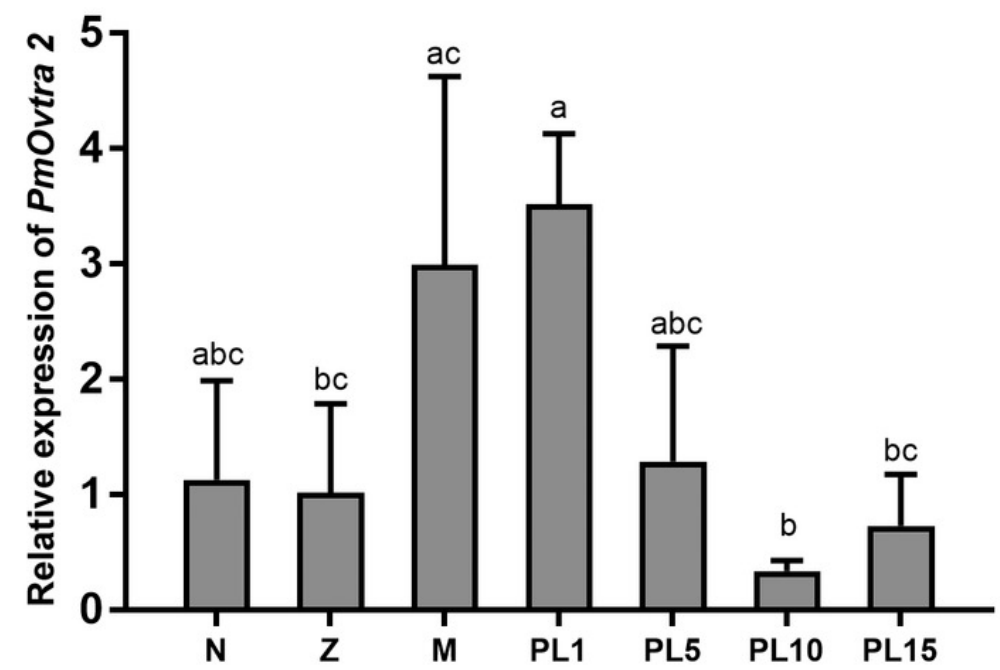

B

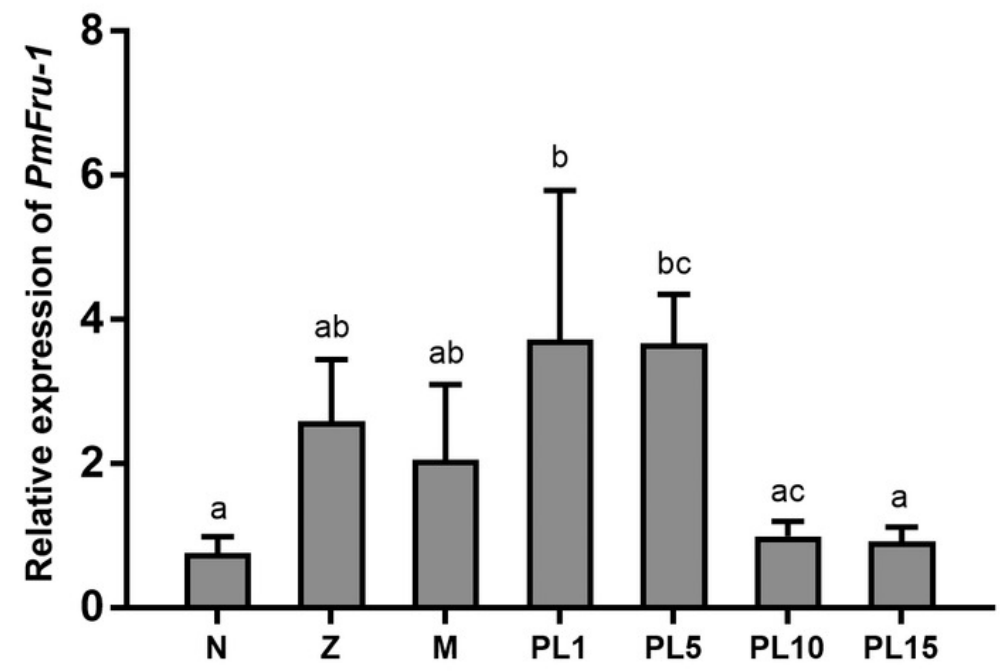

C

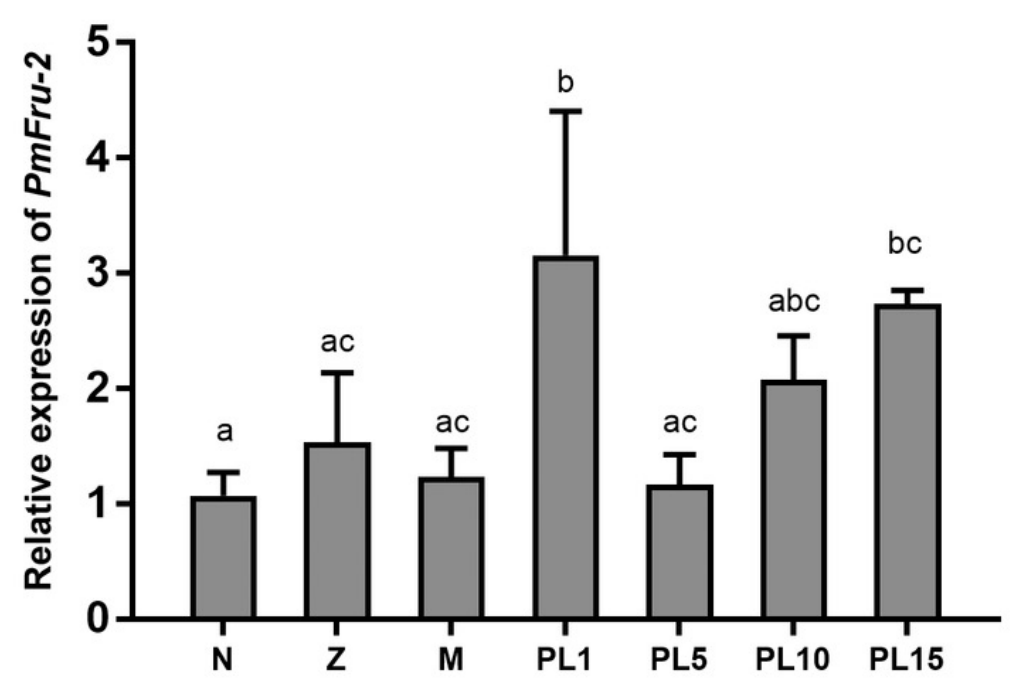




\section{Figure 7}

Tissue distribution of PmOvtra 2, Pmfru-1, and Pmfru-2 in P. monodon.

Tissue distribution of PmOvtra 2, Pmfru-1, and Pmfru-2 in P. monodon. Expressions of PmOvtra 2, Pmfru-1, Pmfru-2 were investigated in eyestalk (ES), central nervous system (CNS), gill, hepatopancreas (HP), heart (Hea), gastrointestinal tract (GI), testis (Tes), and ovary (Ova) by RT-PCR. M and N represented molecular weight markers and negative control, respectively. PmOvtra 2, Pmfru-1 and Pmfru-2 transcripts showed the specific band at 449 bp, 262 bp and $345 \mathrm{bp}$, respectively. The 16s rRNA, showing the band at $152 \mathrm{bp}$, was utilized as internal control.

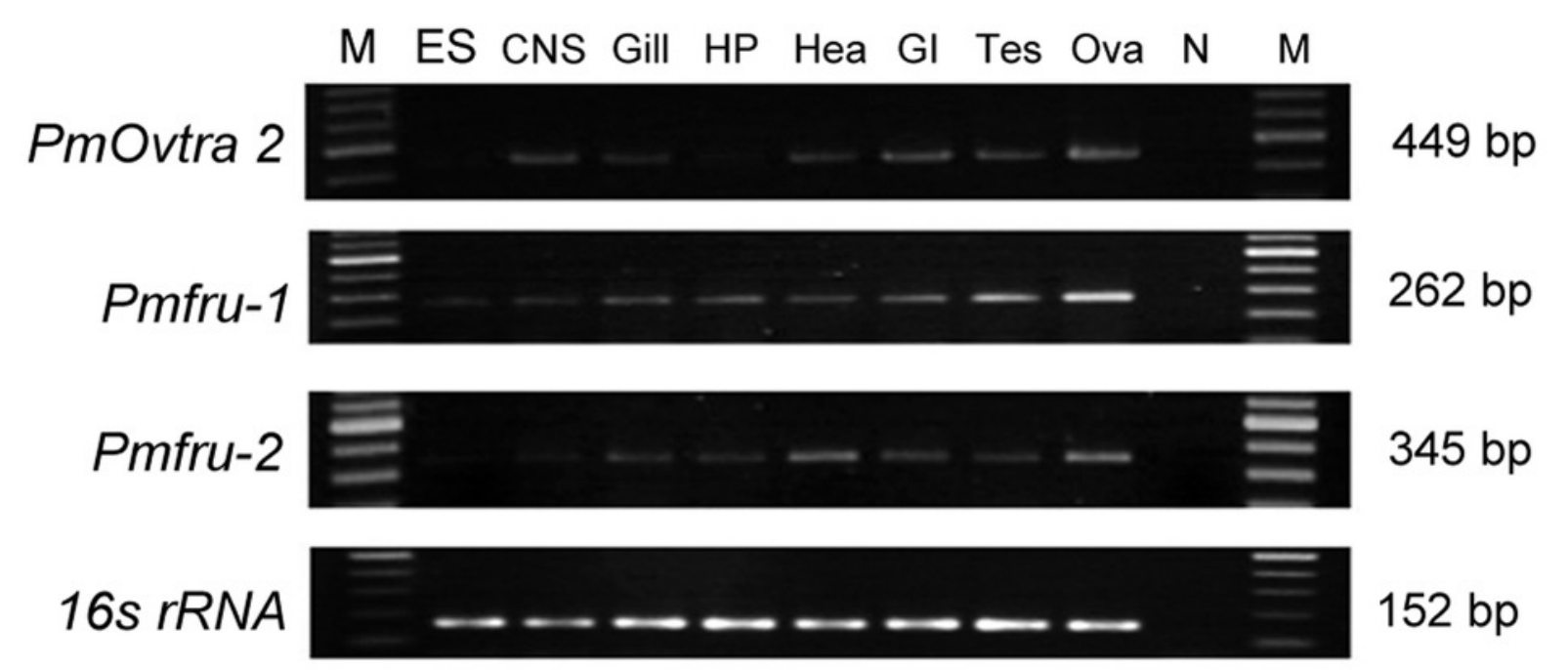




\section{Figure 8}

Relative expressions of PmOvtra 2, Pmfru-1, and Pmfru-2 in testes and ovaries revealed by RT-qPCR.

Relative expressions of PmOvtra 2, Pmfru-1, and Pmfru-2 in testes and ovaries revealed by RT-qPCR. (A) Relative expression of PmOvtra 2. (B) Relative expression of Pmfru-1. (C) Relative expression of Pmfru-2. The mRNA expression level of PmOvtra 2, Pmfru-1 and Pmfru-2 were normalized to the 16s rRNA transcript level. The result showed greatly high expression level of PmOvtra 2, Pmfru-1 and Pmfru-2 in the ovary when compared with the testis. Data represented the mean \pm standard deviation (S.D.). Statistical significance was calculated by unpaired $t$ test. The significant difference was indicated by two asterisks (**) ( $p$ $<0.01)$.

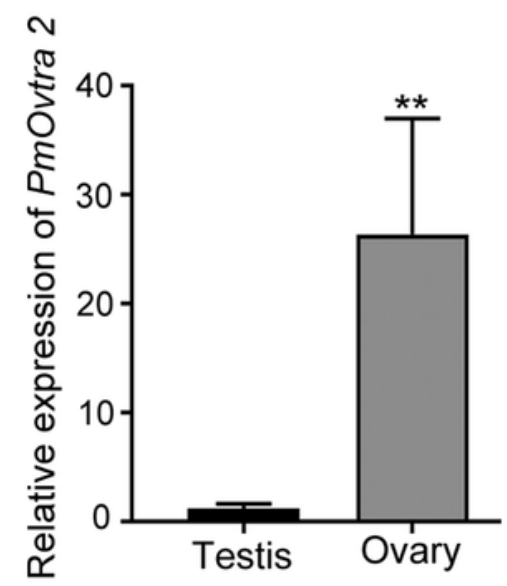

A

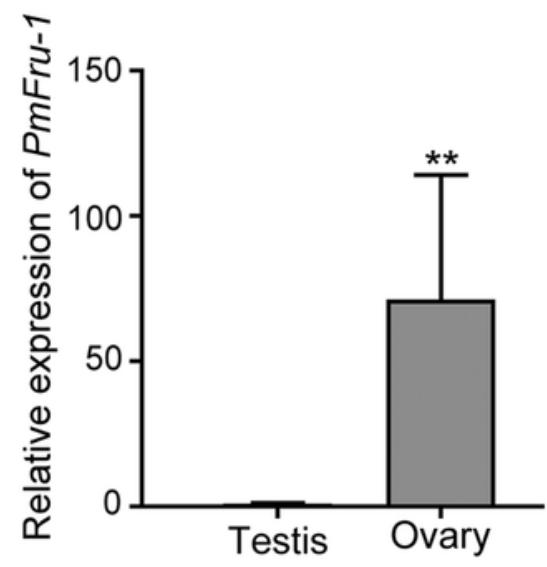

B

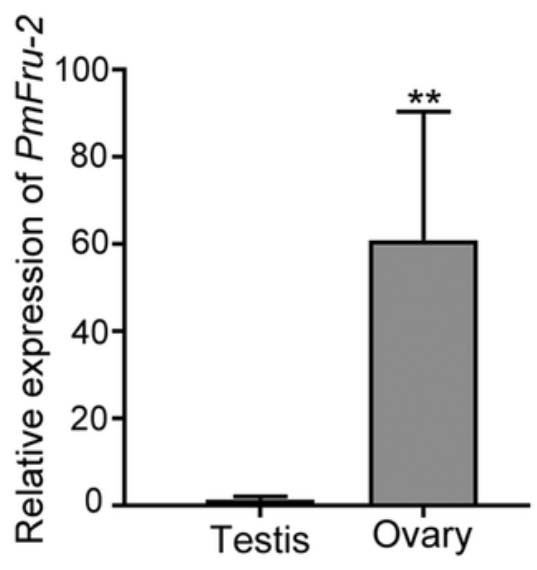

C 